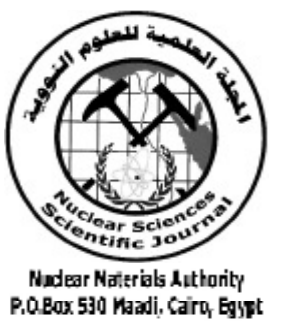

ISSN 2314-5609

Nuclear Sciences Scientific Journal

$7,101-123$

2018

http:// www.ssnma.com

\title{
CONTRIBUTION TO GEOLOGY AND URANIUM DISTRIBUTION OF SOME BASEMENT ROCKS IN EL-MUEILHA AREA, SOUTH EASTERN DESERT, EGYPT
}

\author{
TAREK F. MOHAMMADEN; NAGDY M. F. ABDOU and MAHMOUD M. BADRAN \\ Nuclear Materials Authority, P.O. Box 530, El-Maadi, Cairo, Egypt
}

\begin{abstract}
Metadacite is composed of phenocrysts of plagioclase, quartz, K-feldspar, hornblende and, in less order, biotite. These minerals are embedded in ground mass of felsic and mafic minerals forming the porphyroblast texture. The meta-andesite is mainly composed of plagioclase, hornblende and quartz showing common porphyroblast texture in addition to the descriptive pilotaxitic textures. The more or less availability of the mineral assemblage of chlorite, actinolite, epidote, sericite, zeosite, plagioclase and quartz might support that both the metadacite and metandesite are susceptible to change in temperature and pressure and they were affected by the low greenschist facies metamorphism.

The granitoid rocks are recognized as monzogranite, granodiorite and quartz-diorite. All of them showed the traditional petrographic features and mineral composition. However presence of more than one phase of some main minerals in the same rock may indicate successive magmatic crystallization history. The REE data of the studied granitoids points to a complicated origin of these rocks and their arising from volcanic arc-magmatism with significant role of some minerals, e.g. the orthopyroxenes, clinopyroxenes, plagioclases and zircon, found in parent sources of these granitoids. Both the monzogranite and the granodiorite are considered as uraniferous granites and tend to be of fertile type. The uranium seems to be of magmatic origin, particularly in the monzogranite, and linked to the accessory minerals with probable leaching from its bearing partial-metamectized zircon resulted in a disequilibrium state.
\end{abstract}

\section{INTRODUCTION}

El-Mueilha area is located between Lat. $24^{\circ} 51^{\prime} 30^{\prime \prime}-24^{\circ} 54^{\prime} 00^{\prime \prime} \mathrm{N}$ and Long. $33^{\circ} 59^{\prime}$ and $34^{\circ} 02^{\prime}$ E. The metadacite, meta-andesite and the granitoid rocks occupy a distinct area of the exposed basement rocks in El-Mueilha area.

As it is forming the western part of the Arabian-Nubian Shield, the Egyptian basement complex cover wide areas mainly in the Eastern Desert extending along the Red Sea Coast and the southern part of Sinai Peninsula in addition to local areas in the south western part of the Western Desert. The lithologic units of the basement complex can be distinguished into the layered sequences and the Pan-African. The layered pasammatic schists and gneisses forming substrate for the Pan-African sequences, volcanics, volcano-sedimentary and sedimentary parentages that are variably metamorphosed. The Pan-African witnessed the oceanic and island arc volcanism and sedimentation, prevalence of ophiolites and ophiolitic mélanges, low to moderate grades of metamorphosed in addition to intermediate tholeiitic to calc-alkaline volcanics

Granitoid rocks in the Arabian-Nubian 
Shield include (1) syn- to late-orogenic granitoid assemblages (880-610 Ma) and (2) postorogenic to anorogenic granitoid assemblages (600-475 Ma), previously identified as older and younger granitoids, respectively (Bentor 1985, Noweir et al., 1990). The older granitoids constitute about $27 \%$ of the Eastern Desert basement outcrops (Stern, 1979) and range in composition from quartz diorite to monzogranite. The younger granitoids approximately constitute $30 \%$ of plutonic assemblages in Egypt (Hassan \& Hashad 1990) and commonly form small plutons $(\sim 1-10$ $\mathrm{km}^{2}$ ) widely scattered in the Eastern Desert of Egypt. They are confined to regional structural weakness of NW-SE to N-S directed rifting in the northernmost Afro-Arabia (Stern, 1985). The Egyptian younger granitoids were classified into three phases named I, II and III where phase I is the least differentiated while phase III is the highest differentiated type (Greenberg, 1981). The younger granitoids are calc-alkaline to mildly alkaline rocks with I-type affinity. Some of them have been classified as A-type either post-orogenic subduc- tion-related or anorogenic rift-related (AbdelRahman and Martin, 1990; Jahn et al., 1993; Mohamed, 1996; El-Sayed, 1998; Mohamed and Kanisawa, 1999 and Mohamed et al., 1999).

\section{FIELD GEOLOGY}

El-Mueilha area is located in the south Eastern Desert between Lat. $24^{\circ} 51^{\prime} 30^{\prime \prime}-24^{\circ}$ $54^{\prime} 00^{\prime \prime} \mathrm{N}$ and Long. $33^{\circ} 59^{\prime}-34^{\circ} 02^{\prime} \mathrm{E}$. It is a mountainous area with main four topographic peaks; Gabal Um Rashid, Gabal Dunger Dunqash, Gabal Urf Um Rashid and Gabal ElMueilha which rise up to $814,768,577$ and 704 meter a.s.1., respectively. It is traversed by several Wadis including W. Um Dalil, W. El-Mueilha and W. Um Had (Fig. 1). The metavolcanics, older and younger granitoids are main rock units exposed in the studied area.

Metavolcanics of El-Mueilha could be distinguished into three different lithologic units; El-Mueilha metabasalts (below), Um Dalil meta-andesite-dolerites and Um Hugab meta-

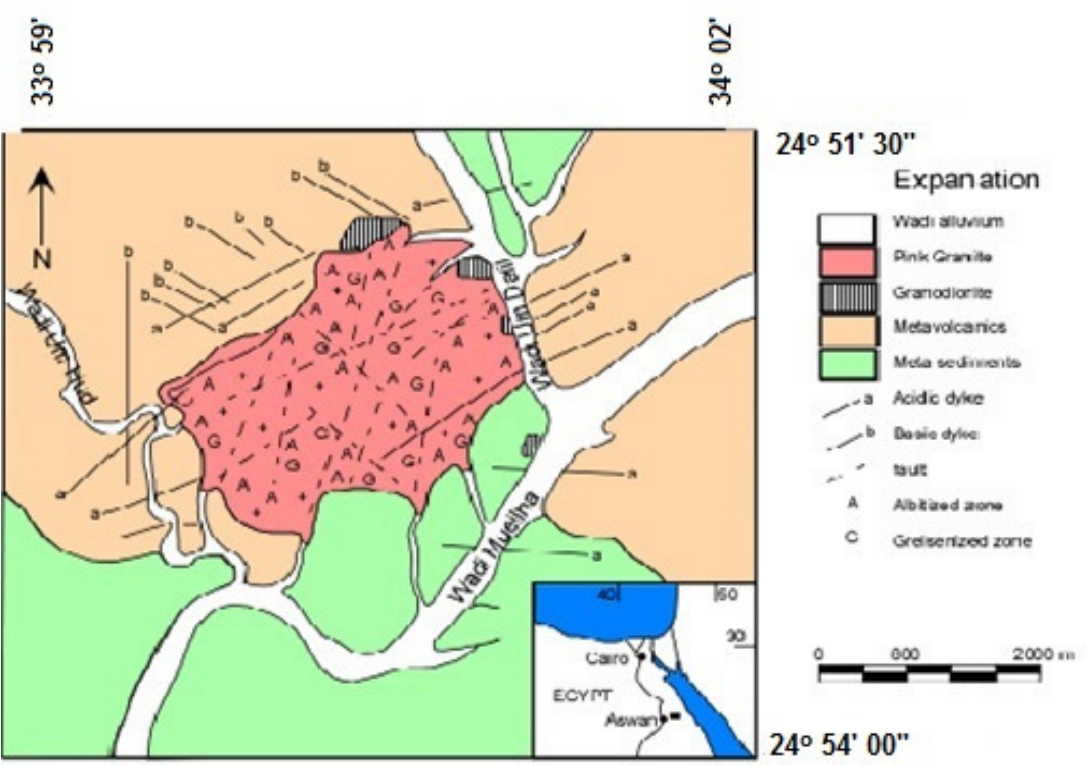

Fig.1: Geologic map of El-Mueilha area (After Azzoz et al., 1994 and Soliman, 1984 
pyroclastics (above). El-Mueilha metabsaslts are composed of weakly metamorphosed basalt flow intercalated with the meta-andesite and metadacite (Hussein and Ghazaly, 1991). Several granitic masses are intruded these metavolcanics (Fig. 2). It is believed that the intrusion happened later to the over thrusting of the younger metavolcanics and is probably related to Idfo-Marsa Alam shear zone (El-Gaby et al., 1988).

The older granitoids are represented by medium- to coarse-grained rocks of granodioritic and quartz-dioritic composition. They are fractured masses with highly weathered surface (Fig. 3), engulfed xenoliths of older rocks of variable size ranging between 2.5 $\mathrm{cm}$. and $23 \mathrm{~cm}$. (Fig. 4). The older granitoids have sharp contacts with the metasediments and metavolcanics and they are intruded by post granitic dykes.

The younger granitic mass in El-Mueilha area has an oval shape attaining approximately $3.5 \& 2.2 \mathrm{~km}$ along NE-SW and NWSE directions, respectively with total area of about $7.5 \mathrm{~km}^{2}$ and exhibiting sharp contact with the surrounding older rocks. It is fine to medium-grained and occasionally has xenoliths of the older rocks (Fig. 5). Post-granitic dykes, quartz and pegmatitic veins transected through the granitic mass with ENE-WSW \& NE-SW directions (Figs. 6\&7), Abu El-Maaty and Ali Bik, 2000.

Kamel (1983) reported 280 dykes in ElMueilha area of varying composition from dolerite, diorite to acidic aplite and granophyres. The main trends of these dykes are the NE-SW and E-W directions with less dominant NWSE direction.

Some alteration features accompany ElMueilha granites and they are represented by greisenization, amazonization and albitization. Such alterations are appeared to be structurally controlled.

Structurally, the main features in El-Mueilha area are the faults, joints, bedding planes and foliations. Faults can be easily identi-

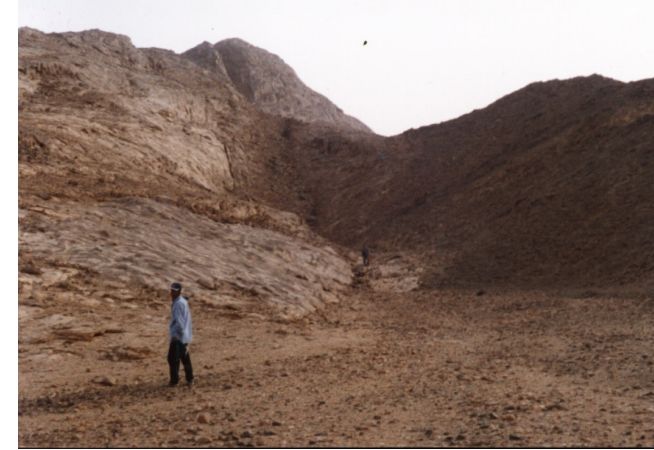

Fig.2: Older granitoid intruding the metavolcanics with sharp contact

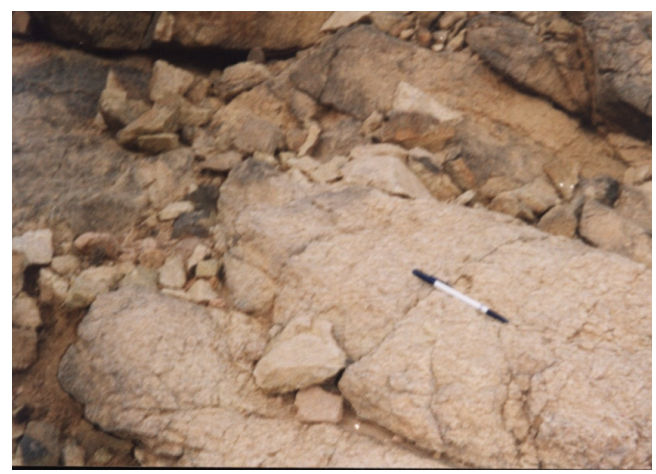

Fig.3: Older granitoids with fracturing and weathering surface

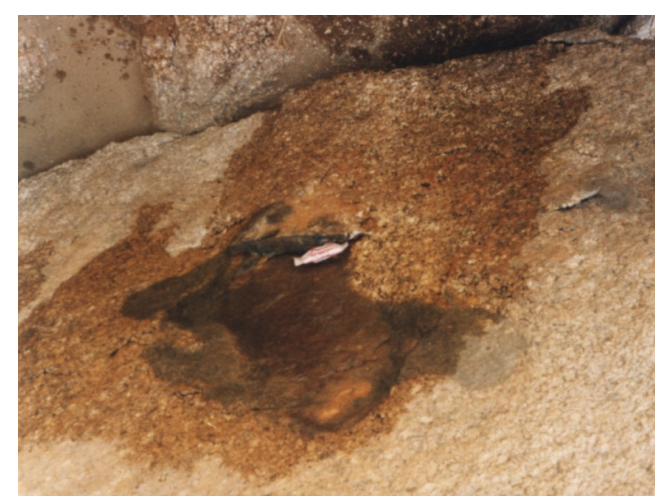

Fig.4: Older granitoid enclosing xenolith of the older rocks 


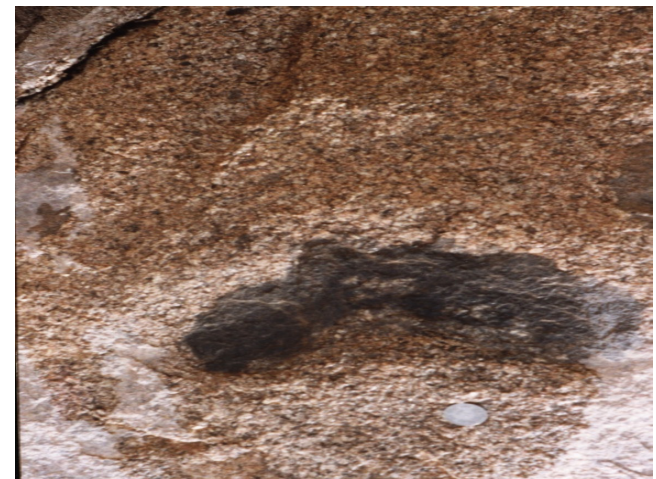

Fig.5: Younger granites engulfing xenolith of the older rocks

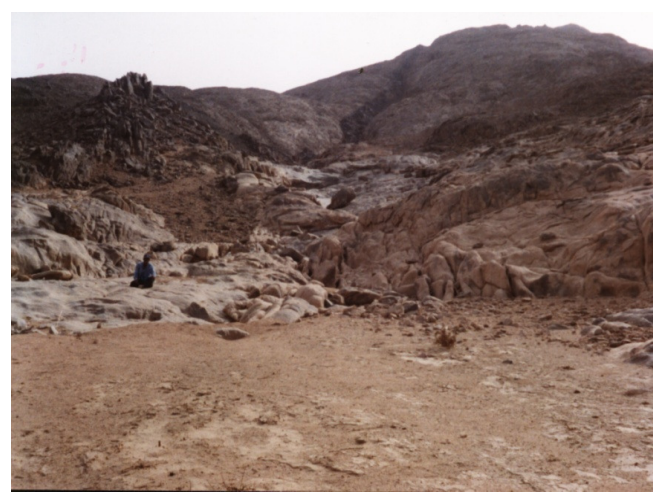

Fig.6: Post-granitic dyke cutting through the granitic mass

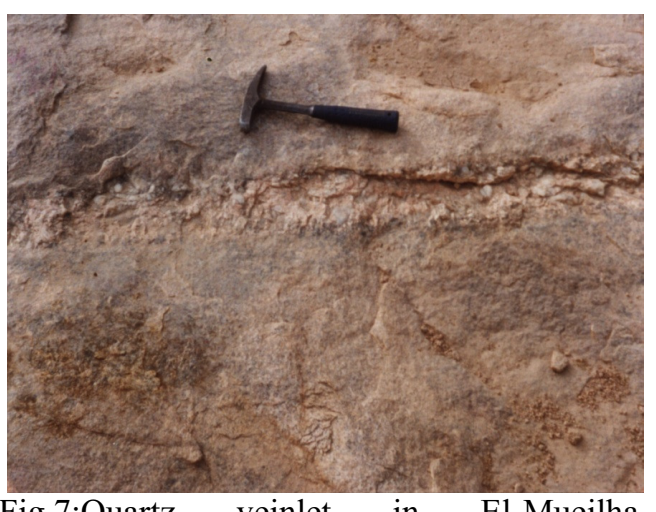

monzogranite fied in three trends as; NE-SW, NW-SE and WNW-ESE in decreasing order. On the other hand, joints are found in various directions of short lines with variable angles (Soliman, 1984).

\section{PETROGRAPHY}

The studied metavolcanics were recognized as meta-andesite and metadacite.

\section{The Meta-Andesite}

The meta-andesite mineralogical constituents include; plagioclase, hornblende and quartz in addition to fewer amounts of biotite and iron oxides. The porphyroblastic texture appears to be common in addition to the pilotaxitic textures.

Plagioclase is widely distributed as coarse to medium, subhedral to euhedral phenocrysts embedded in the rock fragments in the groundmass (Figs. 8-10). It is also found as small laths of random growth orientation that gives the form of the pilotaxitic texture which is characteristic of andesitic rocks (Fig. 11). Referring to the freshness degree and the crystal size, more than one crystallization stage of the plagioclase might be assumed. Some plagioclase crystals are fresh, while others show alteration signs that may destroy the plagioclase's lamellae, however, all plagioclases follow the albite twining law. Oscillatory zoning appears in some crystals that is likely ascribed to mutual relation between the An- and Ab-contents (Fig. 9). On the other hand, normal zoning is recorded by others and seems to be formed due to gradual decreasing of the An-content from the core to the rims which is supported by the gradual decreasing of alteration and lamellae distortion in the same direction (Fig. 10). Occasionally, some crystals are fractured and were filled later on by secondary quartz (Fig. 8).

Mafics are second in abundance, and represented mainly by hornblende and, in subordinate amount, biotite. Hornblende is a subhedral to anhedral prisms of more or less 


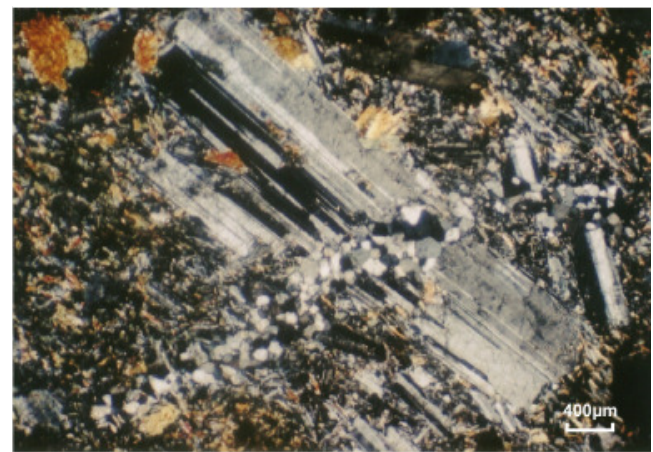

Fig.8: Fresh subhedral fractured plagioclase phenocryst with Albite twinning and the fracture is filled by secondary quartz, XPL.

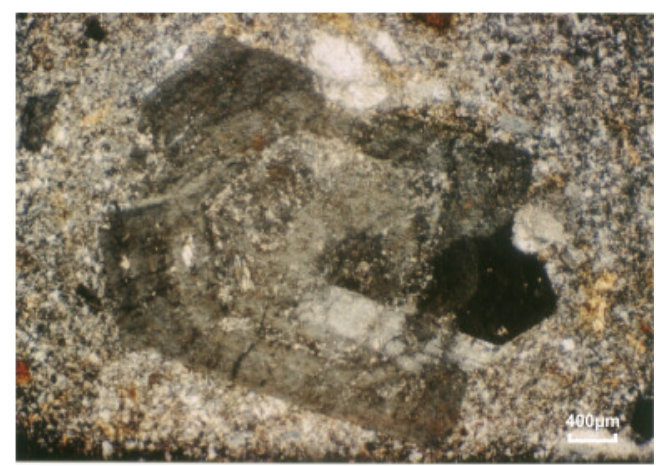

Fig.9: Oscillatory zoned plagioclase phenocrysts, the lamellae were masked due to secondary zoning development, XPL

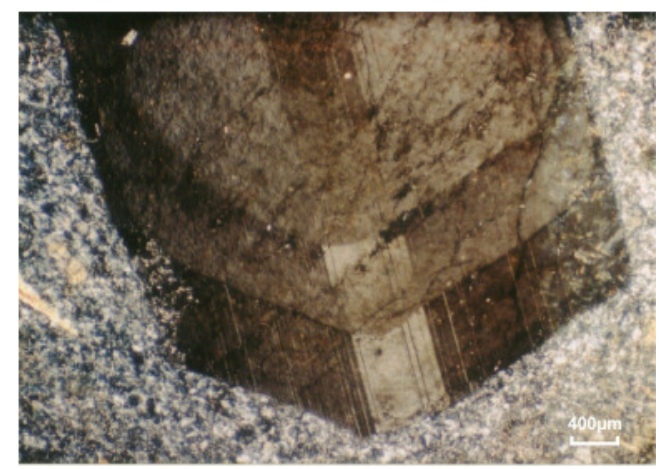

Fig.10: Normal zoned plagioclase phenocrysts showing alteration decreasesg from core to the outer rims in parallel to An-content, XPL

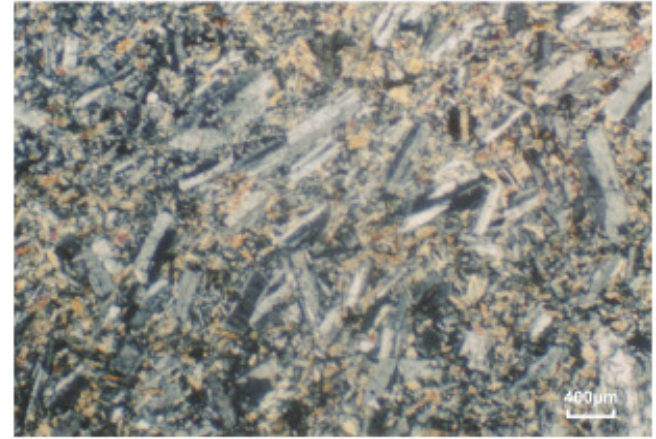

Fig.11: Plagioclase laths embedded in fine grained groundmass with random orientation forming typical pilotaxitic texture, XPL

medium length and shows the typical simple twining and well identified crossed cleavage planes at the hexagonal basal sections (Figs. 12 \& 13). Sometimes, hornblende crystals suffer partial alteration to chlorite and iron oxide. Biotite appears as tiny flakes spread in the groundmass displaying strong pleochorism from the yellow to yellowish brown colors. Quartz could be distinguished into two phases; the primary is the anhedral medium grains of faint undulose extinction (Fig. 13) and secondary is the fracture filling grains of subhedral and anhedral shape cut through the fractured plagioclase (Fig. 8). Other minerals are observed and include zoisite with the typical blue interference color (Fig. 14) and calcite, both of them and the minute opaque particles are embedded in the glassy groundmass.

The groundmass appears to be glassy or composed of fine grains and laths of all major and secondary minerals and it contains numerous phenocrysts of plagioclase and hornblende displaying the porphyroblastic texture and sometimes reveals the pilotaxitic texture.

\section{The Metadacite}

The metadacite is composed mainly of plagioclase, quartz, K-feldspar and mafics which represented by hornblende and, in less order, biotite. The phenocrysts of the major min- 


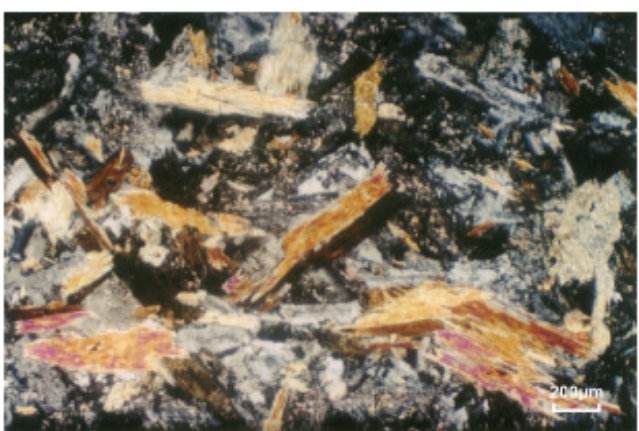

Fig.12: Fresh and partial altered simple twinned hornblende prisms, XPL

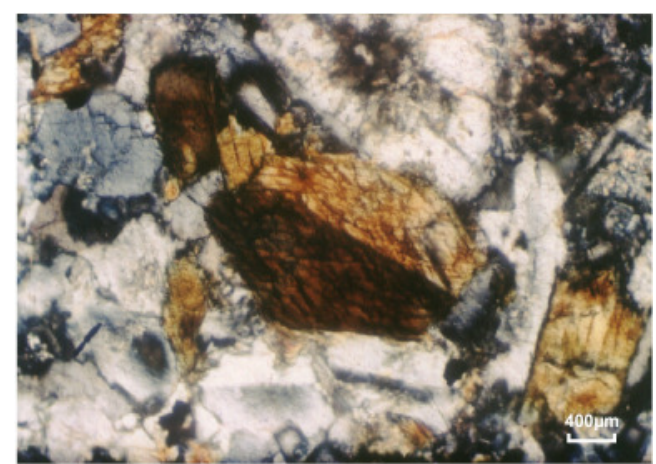

Fig.13: Simple twinned hornblende showing crossed cleavage plans at the hexagonal basel section. And anhedral medium grains of quartz showing faint undulose extinction, XPL

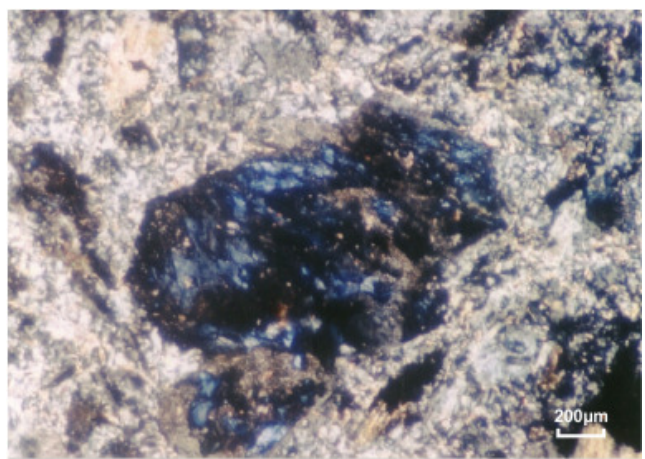

Fig.14: Euhedral zoisite crystal with the typical blue interference color, XPL erals are embedded in the groundmass, which composed of felsic and mafic minerals, forming the porphyritic texture.

Plagioclases are found as partially sausurrtized phenocrysts of mostly subhedral shape, oligoclase composition (Fig. 15). They display both albite and carlsbad twining, in addition to very fine crystals or small laths within the groundmass compositions. Quartz occurs as porphyritic anhedral corroded crystals being embedded in the groundmass (Fig. 16) as well as anhedral fine crystals that form a considerable percentage of the groundmass compositions. Potash feldspars are repre-

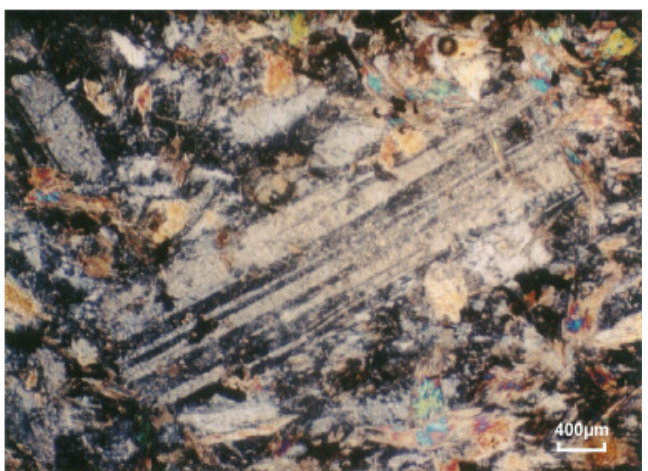

Fig.15: Subhedral plagioclase phenocryst with albite twinning and faint alteration, XPL

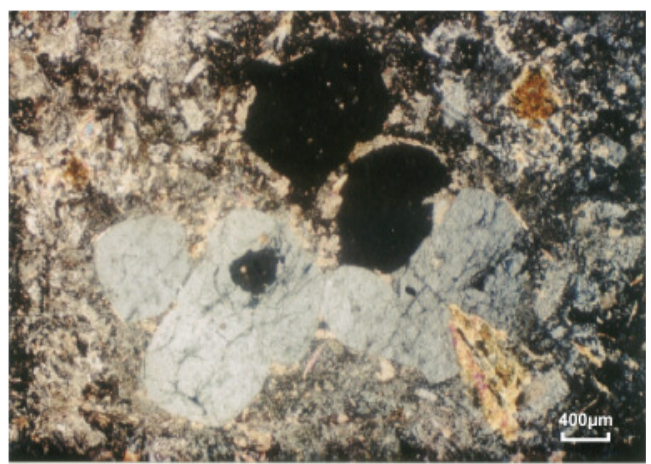

Fig.16: Anhedral quartz crystal embedded in fine grained groundmass, XPL 
sented by porphyry sanidine of subhedral medium grains showing carlsbad twining which the most frequently observed twin law in the monoclinic feldspars (Fig. 17). Occasionally, they show weak alteration to kaolinite.

Mafics are mainly represented by subhedral to anhedral phenocrysts of hornblende that partially altered to chlorite and corroded by the groundmass components (Fig. 18), with small hornblende laths spreading in the groundmass. Biotite is rarely observed and being found only as small laths. Other minerals are recorded in the metadacite, these minerals might be the likely products of the metamorphism including; chlorite with the low grey and anomalous brown colors that are characteristic of some chlorites. Also zoisite and monoclinic clinozoisite are recorded with the characteristic anomalous blue interference color (Fig. 19) in addition to presence of anhedral corroded carbonate that mostly is calcite which distinguished by the twining phenomenon (Fig. 20).

\section{El-Mueilha Granitoids}

El-Mueilha granitoids are classified according to their mineralogical modal analysis (Table 1) into; monzogranite, granodiorite and quartz-diorite rock types using the QAP diagram (Streckeisen, 1976 b), (Fig. 21).

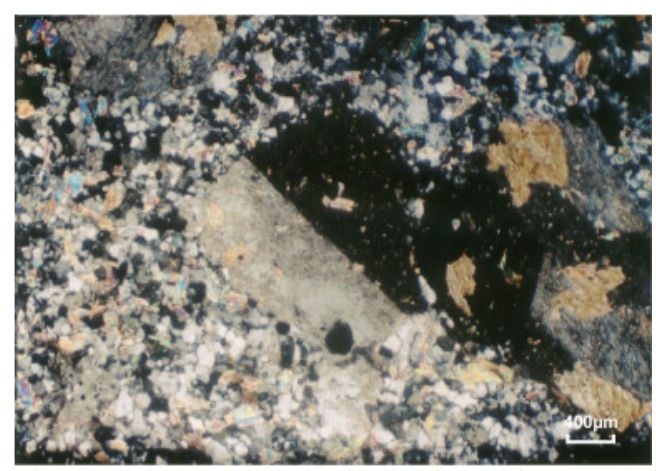

Fig.17: Simple twinned sanidine phenocryst embedded in the groundmass forming the porphyroblast texture, XPL

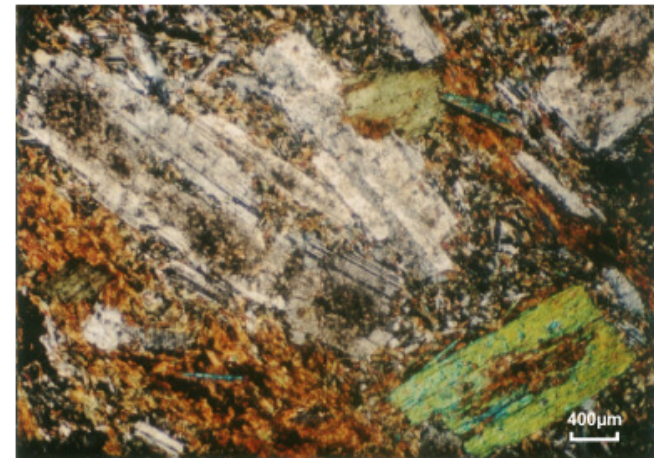

Fig.18: Sausurrtized albite twinned plagioclase phenocrysts and chloritized prismatic hornblende, XPL

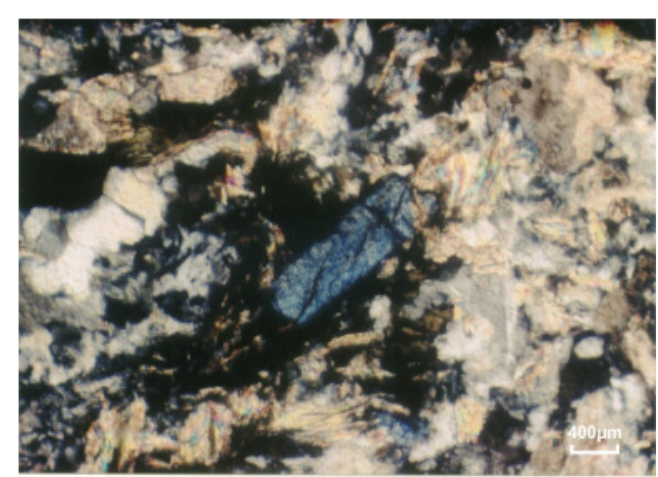

Fig.19: Euhedral zoisite crystal associated with carbonate, XPL

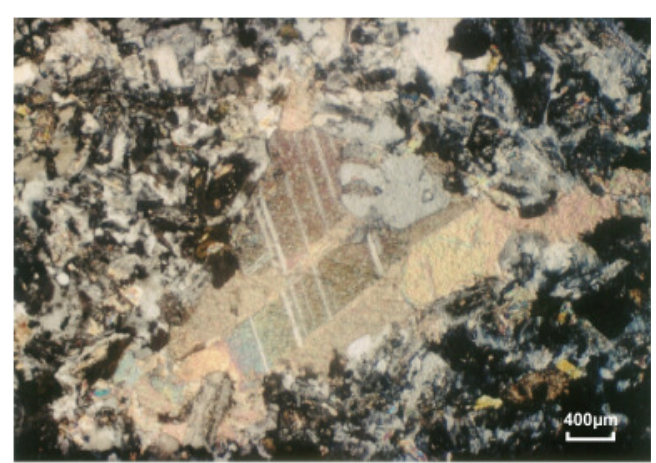

Fig.20: Anhedral corroded carbonate showing typical twining shape, XPL 
Table 1: The modal analysis of the studied granitoids

\begin{tabular}{|c|c|c|c|c|c|c|}
\hline Rock & S. No. & $\overline{Q z}$ & K-Feld. & Plag. & Mafics & Op. + Acc. \\
\hline \multirow{9}{*}{ Monzogranite } & M1 & 45 & 30 & 25 & 0.14 & $\overline{0.1}$ \\
\hline & M2 & 41 & 29 & 28 & 2 & ---- \\
\hline & M3 & 40 & 32 & 24 & 2.5 & 1.5 \\
\hline & M4 & 40 & 29 & 26 & 1.5 & 2.4 \\
\hline & M5 & 38 & 32 & 23 & 2.3 & 2.2 \\
\hline & M6 & 31.5 & 35.5 & 29 & 3.9 & 0.1 \\
\hline & M7 & 40 & 25 & 31 & 3.4 & 0.6 \\
\hline & M8 & 33.5 & 28 & 32.5 & 4.4 & 1.1 \\
\hline & M9 & 39 & 30 & 27 & 3.4 & 1.5 \\
\hline \multirow{6}{*}{ Granodiorite } & M10 & 28 & 22 & 50 & ( & (n) \\
\hline & M11 & 26 & 21.5 & 47.5 & 4.5 & 0.2 \\
\hline & M12 & 22 & 20 & 53 & 3.1 & ---- \\
\hline & M13 & 25 & 23 & 46 & 5.5 & 0.4 \\
\hline & M14 & 23 & 25 & 50 & 2.4 & ------- \\
\hline & M15 & 25 & 24. & 48 & 3.5 & $:-$ \\
\hline \multirow{3}{*}{ Qz-diorite } & M19 & 14 & 4 & 67.5 & 13.5 & i \\
\hline & M20 & 16 & 5 & 66 & 12.6 & 0.4 \\
\hline & M21 & 13 & 4 & 68 & 14.5 & 0.5 \\
\hline
\end{tabular}

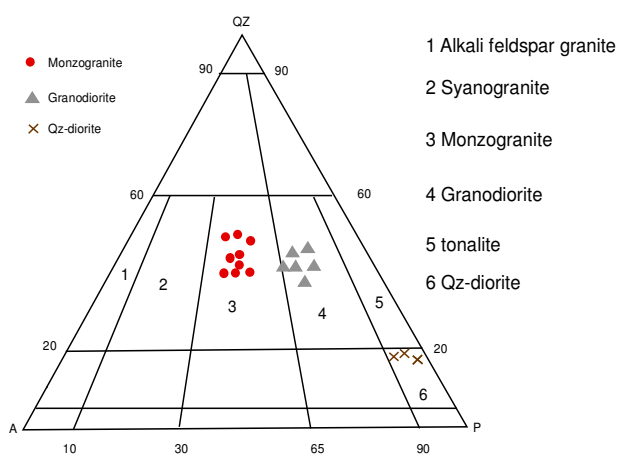

Fig.21: QAP classification diagram, Streckeisen (1976 b)

\section{The Monzogranite}

The monzogranite shows coarse- to medium grained texture with major constituents; quartz, potash feldspars, plagioclase and subordinate amounts of mica (mainly biotite and less common muscovite). Zircon and sphene are recorded as accessory minerals.

Quartz is generally anhedral coarse to medium crystals and exhibits two crystallization phases which are indicated by presence of fine grained anhedral crystals engulfed by the second phase coarse grained quartz (Fig. 22). A regular intergrowth of the quartz and the alkali feldspar is indicated by presence of the graphic texture (Fig. 23).

Orthoclase perthite and, in subordinate amount, cross-hatched (tartan pattern) microcline perthite are of anhedral to subhedral megacrysts (Fig. 24). Occasionally, the $\mathrm{K}$-feldspars show simple twinning (Fig.25) and light alteration to kaolinite. Plagioclase is mostly of oligoclase composition $\left(\mathrm{An}_{14-18}\right)$ and it is represented by coarse, medium to small anhedral to subhedral crystals showing albite twinning of variable sized lamellae (Fig. 26). Presence of zoned and non-zoned crystals as well as fresh and partially altered plagioclase in the same section support more than one crystallization phase (Figs. 26, 27\&29). The normal zoning in plagioclase crystals is likely ascribed to the complete solid solution between albite and anorthite at high temperature that leads to more An-rich core and more Ab-rich rims (Shelly, 1993). Biotite as anhedral flakes of yellow to yellowish green colors is located along the boundaries of the other 


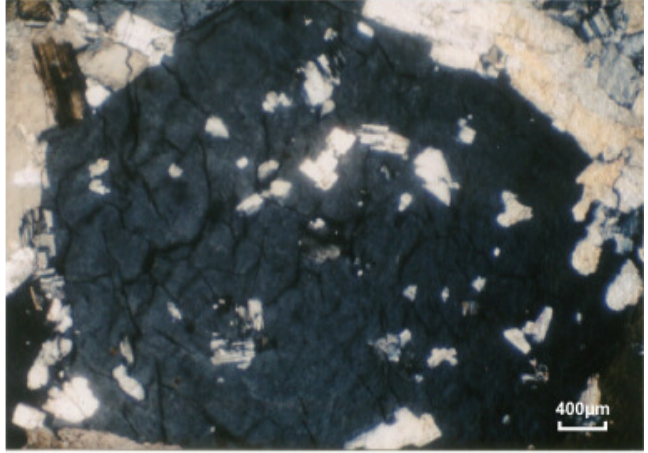

Fig.22: Coarse grained quartz engulfs fine quartz and plagioclase crystals forming poikilitic texture, XPL

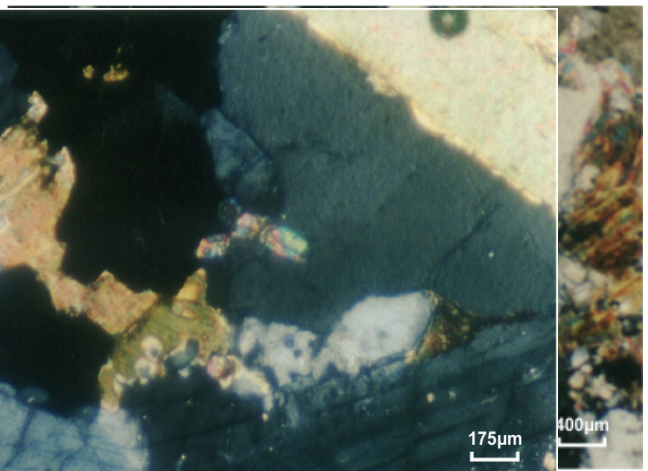

Fig.23: Graphic texture in the studied monzogranite, XPL

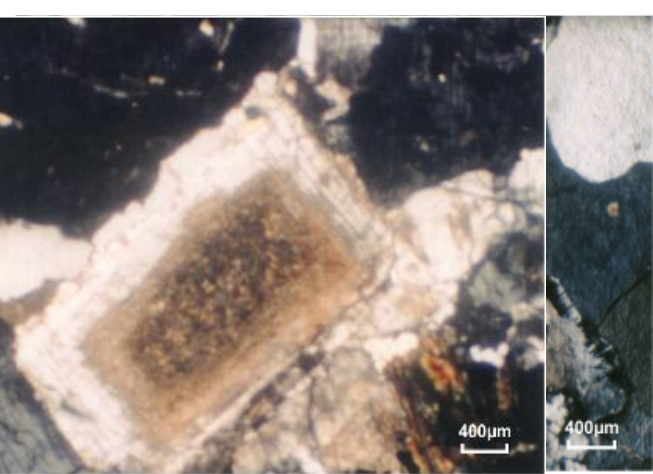

Fig.24: Anhedral microcline perthite megacryst showing the traditional tartan pattern, XPL

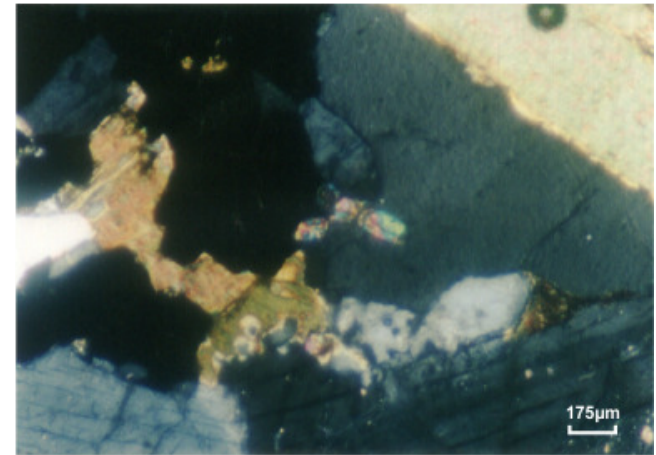

Fig.25: Simple twinned orthoclase and interstitial biotite flake moderate with zircon grain, XPL

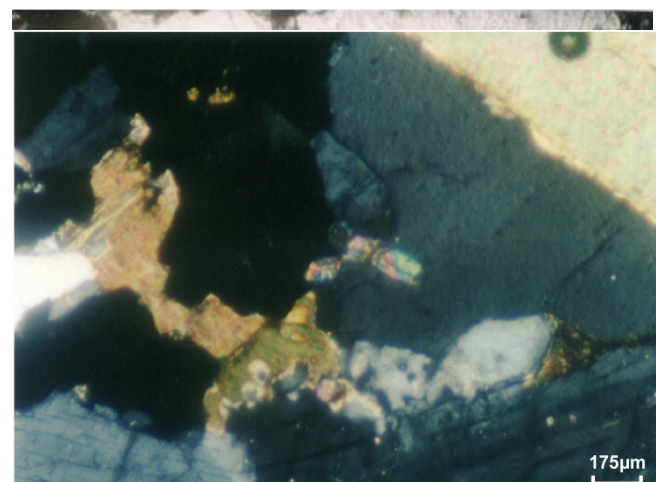

Fig.26: Albite and Carlsbad twinned fresh plagioclases, XPL

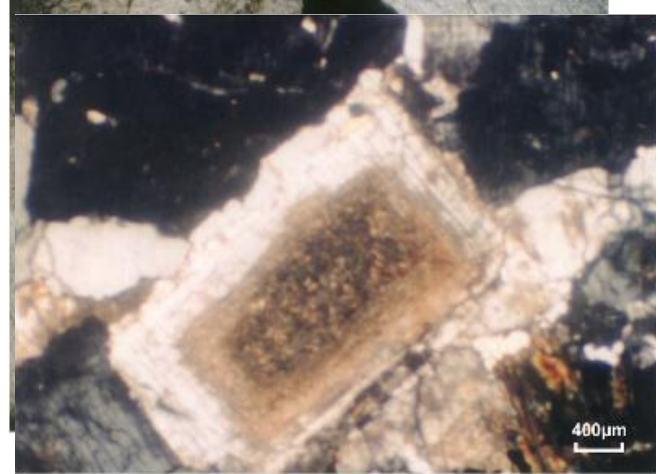

Fig.27: Oscillatory zoned plagioclase crystal, XPL 
major felsic minerals and they show moderate pleochorism and sometimes suffer partial alteration to chlorite (Figs. 25\&28).

In addition, primary muscovite anhedral flakes are observed in subordinate amounts suggesting the peraluminous nature of the monzogranitic magma. Elongated fresh and partially metamectized zircon and wedge shaped sphene are recorded as accessory minerals in El-Mueilha monzogranite (Fig. 29). Secondary minerals as saussurite, kaolinite and iron oxide are present in association with plagioclase, potash feldspar and biotite as their alteration products.

\section{The Granodiorite}

The granodiorite is composed of plagioclase, quartz, potash feldspars to micas. Accessories are mainly represented by zircon crystals. It exhibits subhedral to anhedral granular texture with mineral constituents rank .

Plagioclase of common oligoclase in composition $\left(\mathrm{An}_{22-28}\right)$ is the most abundant mineral in the studied granodiorite occurring mainly as rectangular subhedral crystals of medium to small size and follows the albite law twinning (Figs. 30\&31). Zoning and alteration features are not recorded but sometimes the plagioclase crystals are cracked, due to the differential stresses, and these cracks are filled

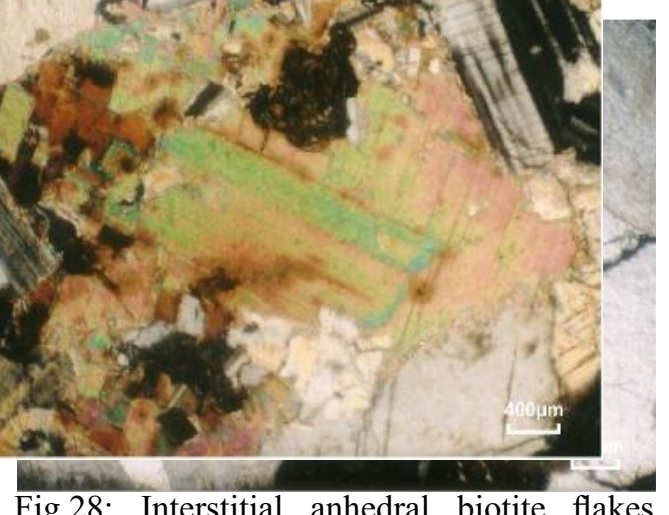
bounded by the quartz and perthite, XPL

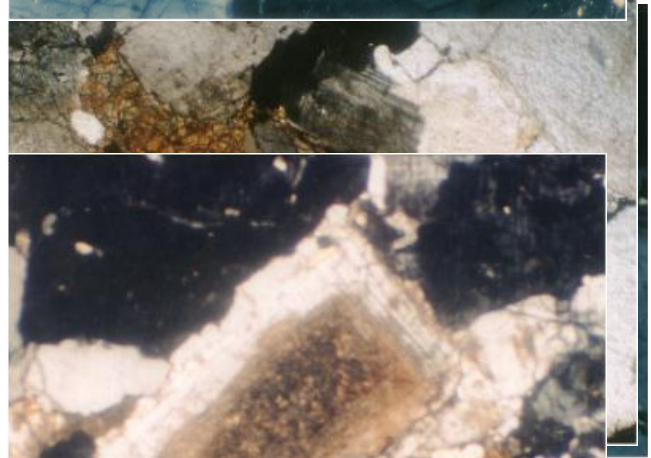

Fig.29: Deformed wedge shape sphene crystal and zoned plagioclase, XPL

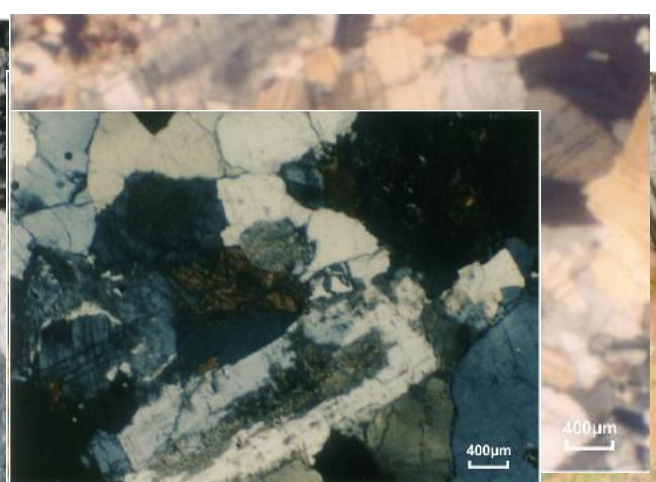

Fig.30: Associations of cracked albite twinned plagioclases. Sometimes the cracks are filled by noncrystaline materials, XPL

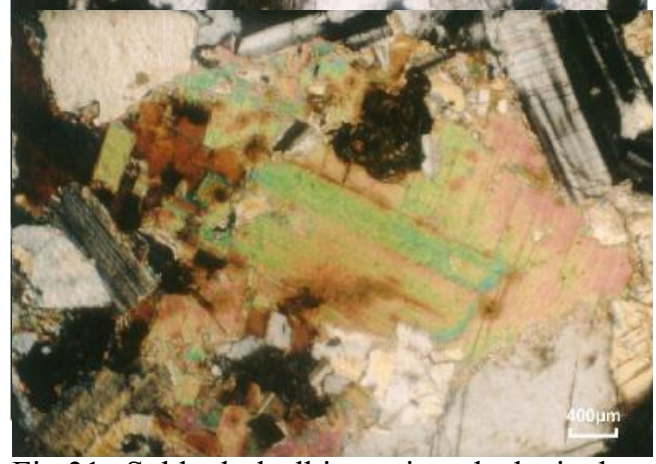

Fig.31: Subhedral albite twinned plagioclase with subhedral to anhedral biotite flacks showing expelled iron oxides. Partial metamect more or less zircon grains, XPL 
with opaque materials. Quartz crystals are commonly of anhedral shape with variable size. Based on the cracking intensity and the intergranular relationship, three phases of quartz could be distinguished. The first phase, seems to be the oldest, includes those quartz grains engulfed by the coarse quartz and the potash feldspars grains; the second one is represented by those quartz grains of intensive cracked, while the third phase and probably the youngest includes the quartz grains of free cracked except on the grain boundaries which may be attributed to the effect of crystal growth (Figs. 32 \& 33). Potash feldspars are mainly perthite megacrysts of string and patchy forms (Figs. $33 \& 34$ ).

The perthite crystals seem to be free from the alteration signs and they enclose numerous fine crystals of plagioclase and quartz forming poikilitic texture. Sometimes the engulfed plagioclases show parallel orientation and display a relative optical continuity with their host potash feldspars (Fig. 34). Such criteria could indicate that these plagioclases are originated as exsolved phase. Biotite occurs as xenomorphic to hypidiomorphic medium to small interstitial biotite flakes (Figs. $31 \& 35$ ) of yellow to brownish yellow in color with moderate pleochorism and display

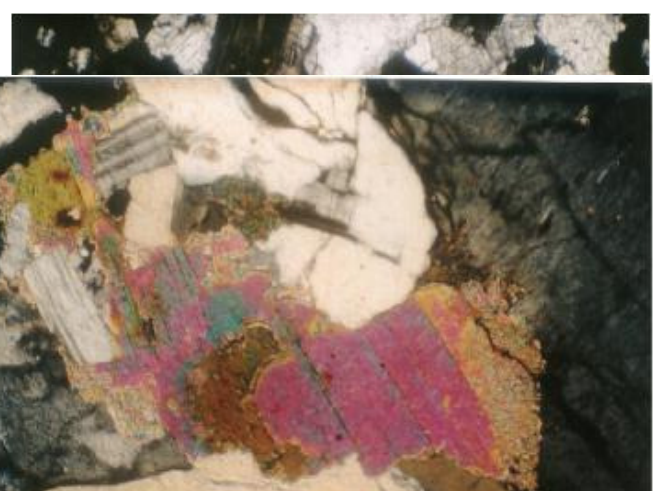

Fig.32: Anhedral coarse grained quartz showing cracks limited to the grain boundaries probably due to effect of crystal growth, XPL

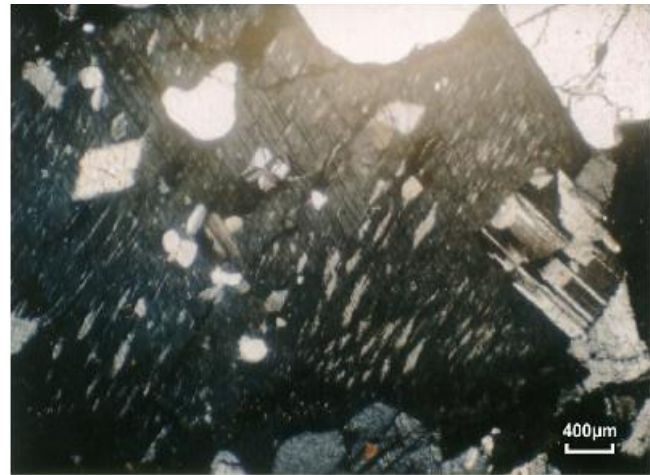

Fig.33: Orthoclase perthite of string type with inclusions from quartz grains. Albite twinned plagioclase corrodes into the perthite, XPL

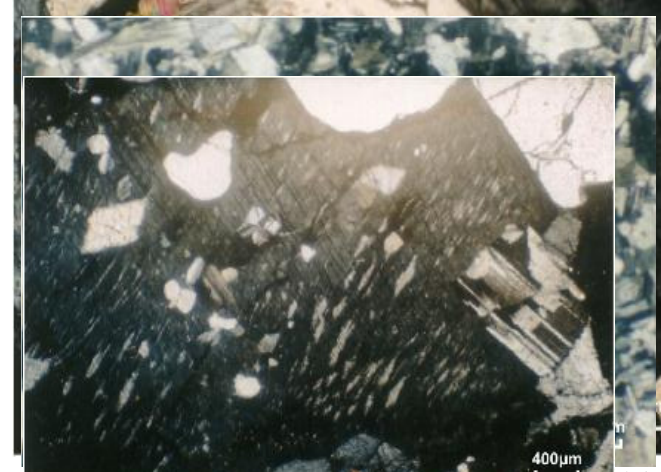

Fig.34: Plagioclase in optical continuity with the hosted perthite, XPL

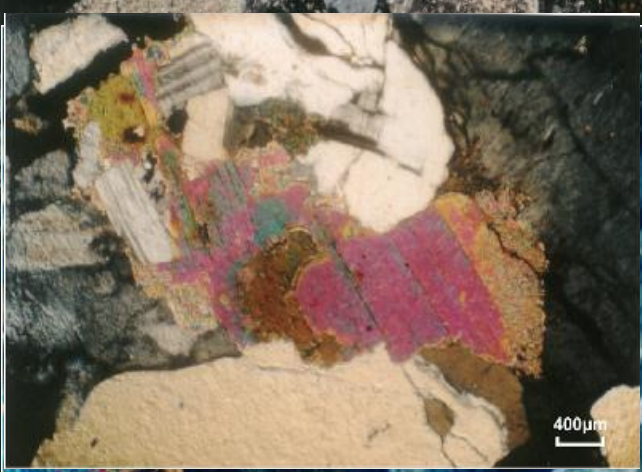

Fig.35: Anhedral biotite flakes associated with quartz and plagioclase, XPL 
faint alteration to chlorite. Iron oxides appear along the biotite cleavage planes as they were expelled out of the biotite flakes. Zircon of more or less oval shape crystals suffer partial metamictization leading to disappearance of the traditional secondary order colors of zircon (Fig. 31).

\section{Quartz-Diorite}

Quartz-diorite is mainly composed of plagioclase, hornblende, biotite and quartz crystals in descending order with anhedral to subhedral texture. Sphene is the only recorded accessory mineral. Saussurite, fine muscovite (sericite) and chlorite are the common secondary minerals.

Plagioclase represents about $66 \%$ of the Qz-diorite mineralogical composition. Its crystals are of subhedral shape, medium size and mostly twinned according to the albite low twinning. Andesine $\left(\mathrm{An}_{32-40}\right)$ is the common plagioclase type with fewer amounts of oligoclase $\left(\mathrm{An}_{22-29}\right)$. The plagioclase crystals show different degrees of alterations as they present in fresh crystals with clear twinning, moderately altered and completely altered crystals with deformed twinning (Figs. 3638). The hornblende of anhedral long prismatic, simple twinned crystals with partial alteration to chlorite is the common mafic minerals (Figs. 38 \& 39). Biotite ranks secondary after the hornblende. It is mostly of fresh flakes displays strong pleochorism from yellow to yellowish brown colors with released of iron oxide along the cleavage planes (Fig. 37). Quartz occurs as anhedral crystals occupy the intergranuler spaces between the other major components (Fig. 40). The quartz crystals appear to be free from the undulose extinction or any other deformation features which reflect absence of the effective outer stresses on the quartz-diorite masses. A cracked wedge sphene appears to be the unique accessory mineral in the studied Qz-diorite (Fig. 41). Fine secondary carbonate crystals fill in-between the boundaries of the major components (Fig. 42).

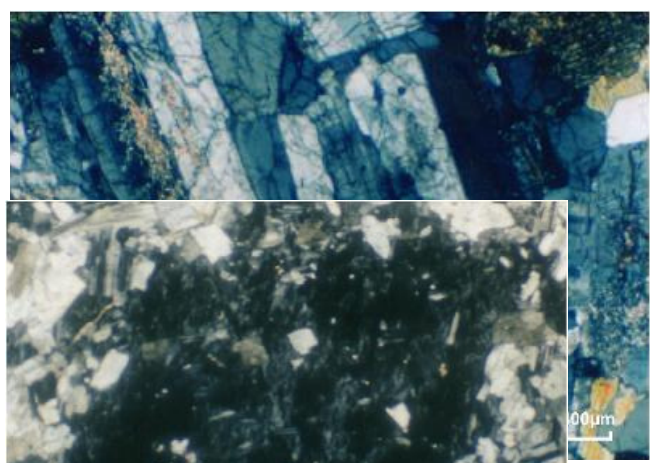

Fig.36: Simple twinned fresh subhedral plagioclase, XPL

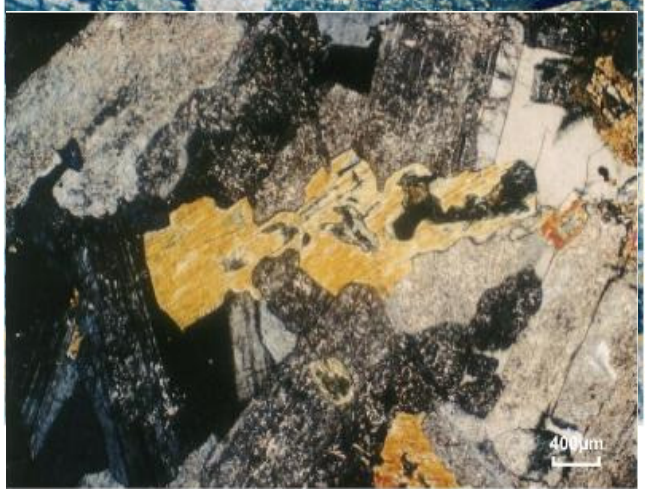

Fig.37: Plagioclase crystals showing partial and complete alteration. Biotite appears as anhedral interstitial flake, XPL

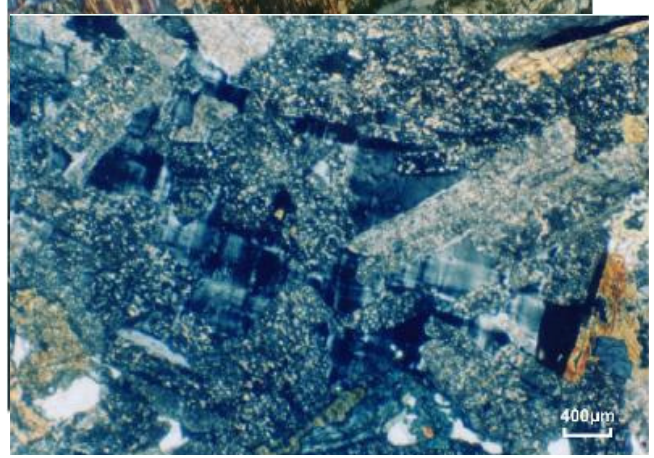

Fig.38: Saussuritized anhedral to subhedral plagioclase crystal corrodes into simple twinned anhedral hornblende, XPL 


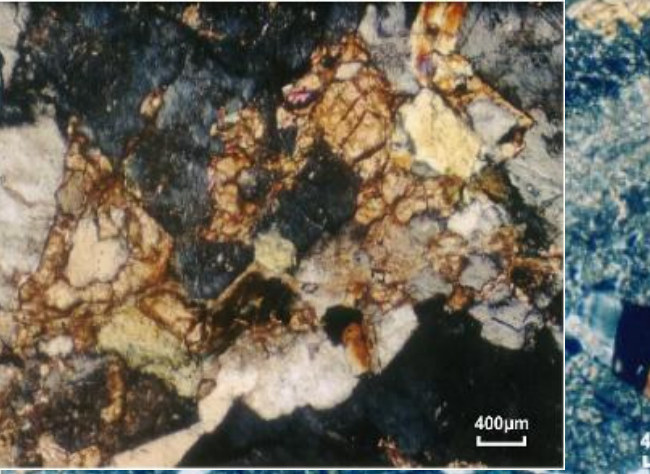

Fig.39: Chloritized subhedral hornblende and quartz grains occupy the inter-granular spaces between the main constituent minerals, XPL

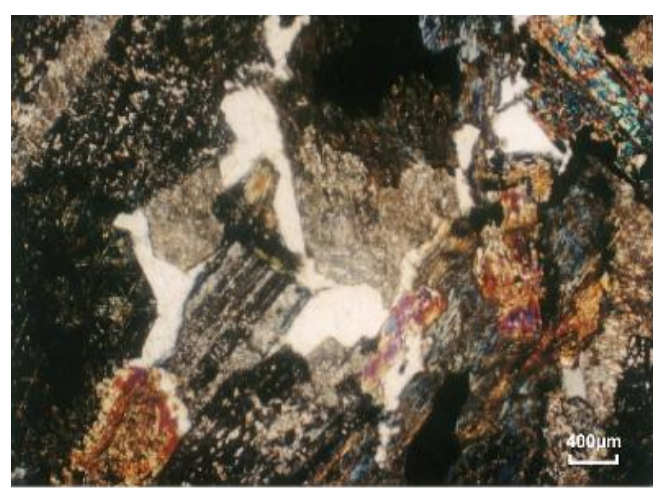

Fig.40: Simple twinned hornblende suffers partial alteration to chlorite. Anhedral quartz crystals are formed between boundaries of the older grains, XPL

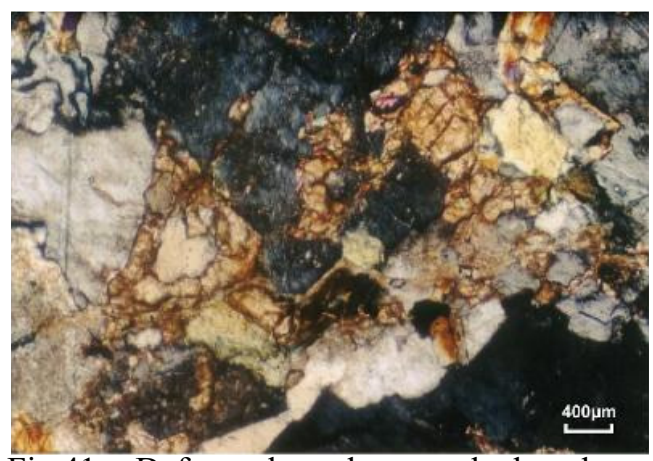

Fig.41: Deformed and cracked sphene crystals, XPL

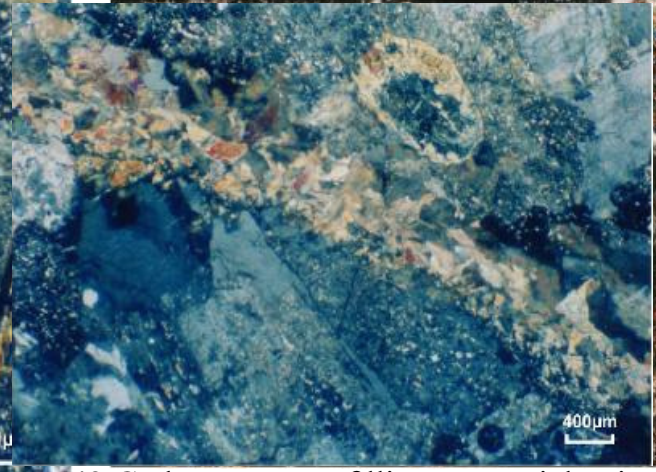

Fig.42:Carbonate as filling materials inbetween boundaries of the components, XPL

\section{REE AND GRANITIOD-MAGMA DIFFERENTIATION ASPECTS}

REE of 12 selected granitoid samples were measured using the WDXRF Spectrometer PAN instrument, National Researches Center-Egyptian Atomic Energy Authority, while $\mathrm{SiO}_{2}$ contents are determined using the spectrophotometric technique in the Nuclear Materials Authority. Their values as well as some calculated ratios are illustrated in Table (2).

The binary relation of the REE and the $\mathrm{SiO}_{2}$ content of the analysed samples (Fig. 43) matching with their tendency to concentrate in the residual magma except the $\mathrm{Eu}$ of the granodiorite due to its favorable retention in the plagioclase minerals. Also, a complicated origin of the studied granitoids could be concluded from domination of the inflected trend and absence of the linear one in the REE-SiO relation where more than one process is expected to influence the magma generation e.g. the fractional crystallization, partial melting and/or assimilation with fractional crystallization (Rollinson, 1993).

$\mathrm{The} \mathrm{Eu} / \mathrm{Sm}$ ratios point to strong -ve Euanomaly in the monzogranite and +ve Euanomaly in both the granodiorite and Qz-diorite (Cullers and Graf, 1984).

The tectonic environment of both the granodiorite and Qz-diorite seems to be the 
Table 2: Values of the $\mathrm{SiO}_{2}(\%)$, REE (ppm) and some ratios in the studied granitoids

\begin{tabular}{|c|c|c|c|c|c|c|c|c|c|c|c|c|}
\hline \multirow[b]{2}{*}{ Element } & \multirow[b]{2}{*}{ M2 } & \multirow[b]{2}{*}{ M3 } & \multicolumn{3}{|c|}{ Monzogranite } & \multicolumn{4}{|c|}{ Granodiorite } & \multicolumn{3}{|c|}{ Qz-diorite } \\
\hline & & & M4 & M6 & M-7 & M10 & M11 & M15 & M17 & M19 & M20 & M21 \\
\hline $\mathrm{SiO}_{2}$ & 72.95 & 72.8 & 73.35 & 72.29 & 74.59 & 69.9 & 69.7 & 68.8 & 67.7 & 63.88 & $\mathbf{5 8 . 4 7}$ & 60.29 \\
\hline La & 42.0 & 36.0 & 32.0 & 45.0 & 34.0 & 19.0 & 24.0 & 28.0 & 20.0 & 8.90 & 6.50 & 10.9 \\
\hline $\begin{array}{l}\text { Ce } \\
\text { Nd }\end{array}$ & $\begin{array}{l}72.0 \\
45.0\end{array}$ & $\begin{array}{l}\text { 70.0 } \\
\mathbf{3 6 . 0}\end{array}$ & $\begin{array}{l}87.0 \\
48.0\end{array}$ & $\begin{array}{l}69.0 \\
27.0\end{array}$ & $\begin{array}{l}85.0 \\
33.0\end{array}$ & $\begin{array}{l}55.0 \\
19.0\end{array}$ & $\begin{array}{l}44.0 \\
21.0\end{array}$ & $\begin{array}{l}44.0 \\
24.0\end{array}$ & $\begin{array}{l}64.0 \\
27.0\end{array}$ & $\begin{array}{l}19.0 \\
6.20\end{array}$ & $\begin{array}{l}12.0 \\
5.80\end{array}$ & $\begin{array}{l}14.0 \\
6.50\end{array}$ \\
\hline Sm & 8.50 & 15.0 & 13.0 & 12.0 & 9.00 & 2.90 & 2.60 & 3.00 & 3.20 & 0.91 & 0.89 & 0.78 \\
\hline Eu & 0.92 & 0.39 & 01.1 & 0.69 & 0.48 & 1.90 & 1.60 & 2.50 & 2.40 & 0.47 & 0.33 & 0.38 \\
\hline Gd & 6.70 & 8.00 & 5.70 & 5.90 & 3.80 & 4.10 & 3.50 & 4.10 & 3.20 & 1.30 & 1.00 & 0.99 \\
\hline Dy & 8.16 & 9.40 & 5.16 & 7.20 & 9.20 & 2.70 & 3.10 & 3.40 & 2.82 & 1.30 & 1.10 & 1.17 \\
\hline $\mathbf{E r}$ & 3.20 & 1.90 & 2.60 & 2.40 & 1.70 & 1.50 & 1.20 & 1.07 & 1.45 & 0.61 & 0.55 & 0.53 \\
\hline $\mathbf{Y b}$ & 2.80 & 2.65 & 3.21 & 2.23 & 1.98 & 1.08 & 0.97 & 0.95 & 1.02 & 0.65 & 0.75 & 0.81 \\
\hline Lu & 1.02 & 0.65 & 0.83 & 0.95 & 0.77 & 0.19 & 0.21 & 0.20 & 0.14 & 0.17 & 0.15 & 0.16 \\
\hline$(\mathbf{L a} / \mathbf{S m}) \mathbf{n}$ & 3.11 & 1.51 & 1.55 & 2.36 & 2.37 & 4.11 & 5.79 & 5.91 & 3.92 & 6.23 & 4.66 & 8.74 \\
\hline Average & & & & & 2.18 & & & & 4.39 & & & 6.57 \\
\hline$(\mathbf{G d} / \mathbf{L u}) \mathbf{n}$ & 0.82 & 1.53 & 0.85 & 0.78 & 0.61 & 2.68 & 2.07 & 2.55 & 2.84 & 0.94 & 0.81 & 0.77 \\
\hline Average & & & & & 0.92 & & & & 2.54 & & & 0.84 \\
\hline$(\mathbf{L a} / \mathbf{L u}) \mathbf{n}$ & 4.27 & 5.74 & 4.00 & 4.92 & 4.58 & 10.4 & 11.9 & 14.5 & 14.7 & 5.45 & 4.49 & 7.07 \\
\hline Average & & & & & 4.70 & & & & 12.88 & & & 5.67 \\
\hline Eu/Sm & 0.11 & 0.03 & o.o8 & 0.06 & 0.05 & 0.66 & 0.62 & 0.83 & 0.75 & 0.52 & 0.37 & 0.49 \\
\hline Average & & & & & 0.07 & & & & 0.72 & & & 0.46 \\
\hline
\end{tabular}
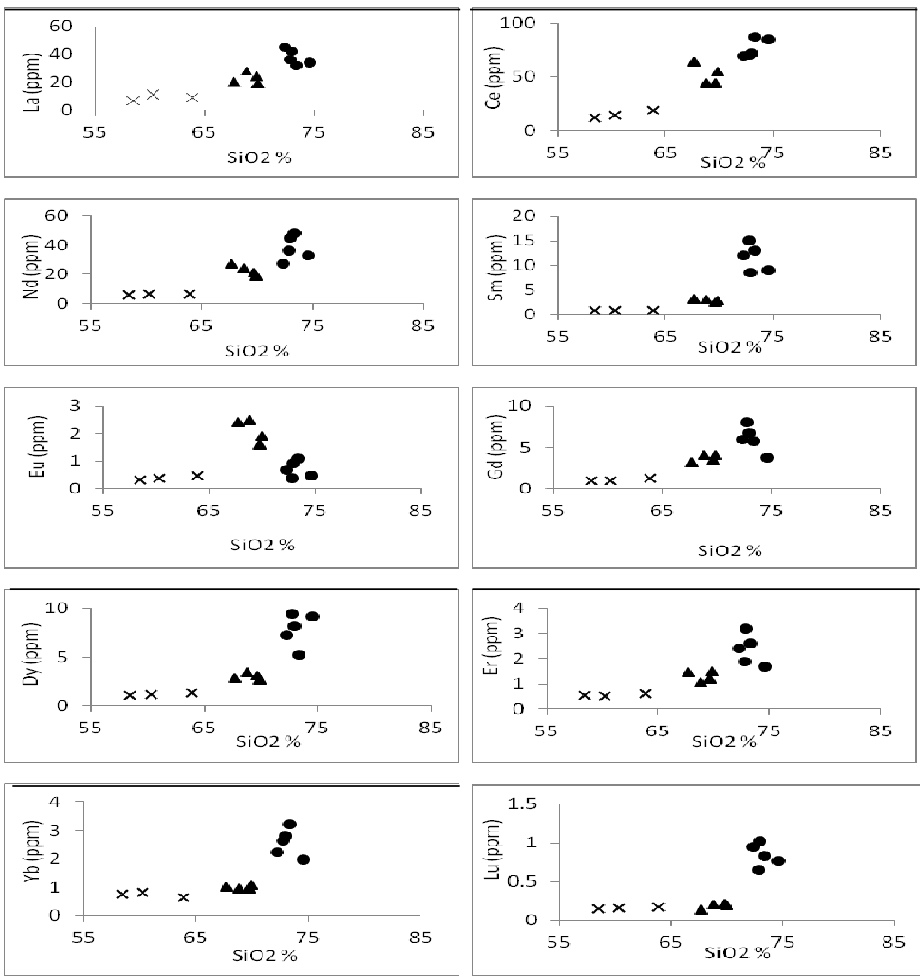

Fig.43: $\mathrm{SiO}_{2}$-REE binary relation of the studied monzogranite $(\bullet)$, granodiorite $(\boldsymbol{\Lambda})$ and the Qz-diorite $(\mathbf{x})$ 
island arc- and volcanic arc-magmatism as their normalized $(\mathrm{La} / \mathrm{Lu})_{\mathrm{n}}$ ratios locate within the range of 5-77.5 for the corresponding ratio of the rocks originated from similar tectonomagmatic environments (Cullers and Graf, 1984). The monzogranite is likely expected to be arising from similar tectonic environment where its average $(\mathrm{La} / \mathrm{Lu})_{\mathrm{n}}$ is very close to the mentioned range.

Normaliztion of the REE data were processed relative to the chondritic values after Taylor and Mclennan, 1985, (Figs. 44 - 46).

The REE normalized pattern of quartzdiorites appears to have generally moderate fractionation $\left[(\mathrm{La} / \mathrm{Lu})_{\mathrm{n}}\right.$ ranging between 4.49 to 7.07 and average value equals 5.67] with enriched LREE branch (average $(\mathrm{La} / \mathrm{Sm}$ ) value equals 6.57 ) relative to faint enriched HREE pattern (average $(\mathrm{Gd} / \mathrm{Lu})_{n}$ value equals 0.84). Such REE fractionation could be explained by presence of orthopyroxenes and clinopyroxenes in the source rock and their slightly lower partition coefficient regarding the LREE than for HREE, additionally presence of hornblendes in the Qz-dioritic melt enhance the HREE and support their faint enrichment as has been shown from the normalized pattern. This conclusion is likely to be reasonable with basic and intermediate magma.

The observed faint positive Eu-anomaly with average $\mathrm{Eu} / \mathrm{Sm}$ equals 0.46 may indicate that plagioclases have minor importance in the history of Qz-dioritic magma generation.

The granodiorite displays high fractionated REE normalized pattern $\left[(\mathrm{La} / \mathrm{Lu})_{\mathrm{n}}\right.$ ranging from 10.4 to 14.7 and 12.88 in average], with moderate fractionated LREE $\left[(\mathrm{La} / \mathrm{Sm})_{n}\right.$ ranges from 3.92 to 5.91 with an average of 4.39 ] and obvious depletion in the fractionated HREE $\left[(\mathrm{Gd} / \mathrm{Lu})_{\mathrm{n}}\right.$ values that ranging from 2.07 to 2.84 with an average value equals 2.54].

The HREE depletion could be ascribed to the retention of both hornblende and most of zircon in the parent rock from which the

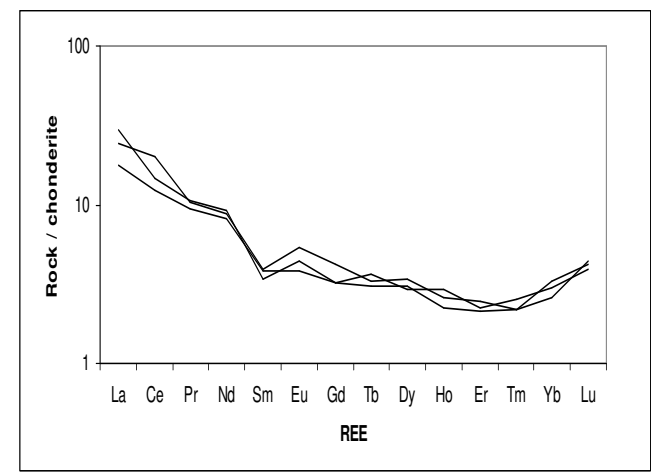

Fig.44: The REE-normalized pattern of the Qz-diorite

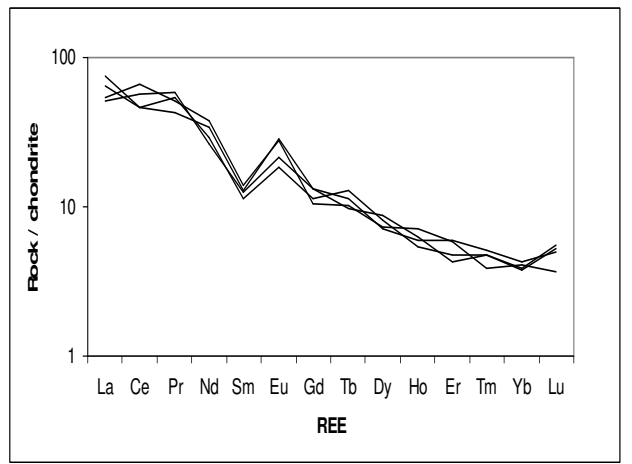

Fig.45: The REE-normalized pattern of the granodiorite

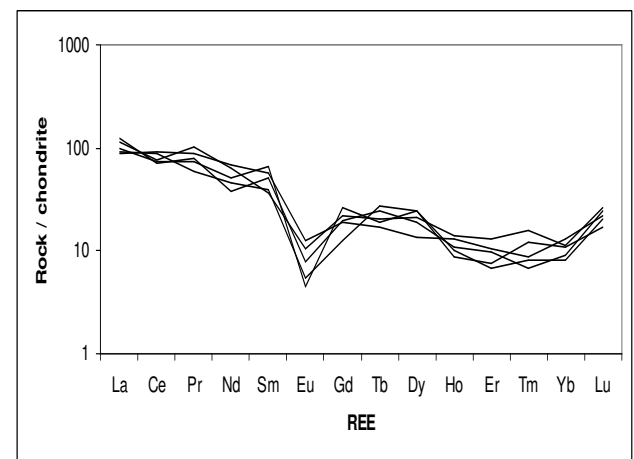

Fig.46: The REE-normalized pattern of the monzogranite 
granodioritic magma was evolved. Such assumption appears to be accepted where it matches with absence of hornblende from the granodioritic mineral composition and presence of rare amount of zircon as been observed from the petrographic study.

Accumulation of plagioclase crystals in the granodioritic melt and/or the hornblende fractionation are the probable mechanisms responsible for the observed strong positive Eu-anomaly which is supported by the Eu/Sm that varies from 0.62 to 0.83 with an average values equals 0.72 (Taylor et al., 1981 \& Fowler and Doig, 1983).

The monzogranite shows fractionated REE pattern of average $(\mathrm{La} / \mathrm{Lu})_{\mathrm{n}}$ equals 4.70 with slight enrichment of $\mathrm{LREE}_{\mathrm{n}}\left[(\mathrm{La} / \mathrm{Sm})_{\mathrm{n}}=\right.$ 1.51-3.11 with an average value of 2.18] relative to faint enrichment of the HREE $[(\mathrm{Gd} /$ $\mathrm{Lu})_{\mathrm{n}}=0.61-1.53$ with an average value of $0.92]$.

The strong negative Eu-anomaly (with average $\mathrm{Eu} / \mathrm{Sm}$ equals 0.07 ) supports major removal of plagioclases from the felsic melt by fractionation and/or retention of most feldspars in the parent rock from which the monzogranitic magma was driven.

The high oxygen activity of the parent monzogranitic melt due to volatile saturation is another probable interpretation for the negative Eu-anomaly (Grenne and Roberts, 1998), where the oxygen activity of the melt would be sufficiently high to keep Eu at the trivalent state and hence detain its admission into the accumulating plagioclases.

\section{U AND Th DISTRIBUTION SIGNIFICANCES}

Uranium and thorium contents of both monzogranite and granodiorite were determined radiometrically using the Multi-channel Gamma Spectrometer with $\mathrm{NaI}(\mathrm{Tl})$ detector, as well as chemically using the LASER instrument; both instruments are installed in the Nuclear Materials Authority (NMA). The corresponding $\mathrm{Zr}, \mathrm{Sr}$ and $\mathrm{Ba}$ in the measured samples are determined (ppm values) using the Atomic Absorption technique. Values of the radiometric and chemical measured uranium and thorium in the studied rocks as well as the other trace elements are illustrated in Table (3).

Table 3: Spectrometric and chemical measurements of uranium and thorium in ElMueilha monzogranite and granodiorite

\begin{tabular}{|c|c|c|c|c|c|c|c|c|c|c|}
\hline \multirow[t]{2}{*}{ Rock } & \multirow[t]{2}{*}{ S. No. } & \multicolumn{3}{|c|}{ Rad. Measuring } & \multicolumn{3}{|c|}{$\begin{array}{r}\text { Chem. Measuring } \\
\text { (ppm) }\end{array}$} & \multicolumn{3}{|c|}{$\begin{array}{r}\text { Trace Elements } \\
\text { (ppm) }\end{array}$} \\
\hline & & eU & eTh & eU/eTh & $\mathbf{U}^{-}$ & Th & U/Th & $\mathbf{Z r}$ & $\mathbf{S r}$ & $\mathbf{B a}$ \\
\hline \multirow{8}{*}{ Monzogranite } & M1 & 0 & $\wedge$ & 0.63 & 12 & 27 & 0.44 & 67 & 182 & 592 \\
\hline & M2 & 6 & 10 & 0.6 & 16 & 32 & 0.5 & 67 & 183 & 638 \\
\hline & M4 & 5 & 9 & 0.56 & 9 & 18 & 0.5 & 60 & 113 & 456 \\
\hline & M5 & 14 & 12 & 1.17 & 13 & 25 & 0.52 & 77 & 131 & 621 \\
\hline & M6 & 15 & 13 & 1.15 & 6 & 22 & 0.27 & 70 & 118 & 543 \\
\hline & M7 & 9 & 12 & 0.75 & 14 & 26 & 0.54 & 67 & 105 & 617 \\
\hline & M8 & 26 & 21 & 1.24 & 22 & 18 & 1.22 & 77 & 128 & 555 \\
\hline & M9 & 17 & 18 & 0.94 & 6 & 21 & 0.29 & 62 & 114 & 490 \\
\hline \multirow[t]{4}{*}{ Average } & & 12.1 & 12.88 & 0.88 & 12.3 & 23.6 & 0.54 & & & \\
\hline & Mi1 & 7 & 17 & $\overline{0.41}$ & $13^{-}$ & 15 & 0.87 & $\overline{43}$ & 157 & -533 \\
\hline & M12 & 9 & 19 & 0.47 & 14 & 24 & 0.85 & 55 & 117 & 335 \\
\hline & M13 & 11 & 17 & 0.65 & 8 & 22 & 0.36 & 48 & 114 & 435 \\
\hline \multirow{5}{*}{ Granodiorite } & M14 & 13 & 18 & 0.72 & 7 & 27 & 0.26 & 58 & 126 & 443 \\
\hline & M15 & 12 & 23 & 0.52 & 20 & 54 & 0.37 & 30 & 121 & 538 \\
\hline & M16 & 12 & 28 & 0.43 & 11 & 38 & 0.29 & 36 & 125 & 433 \\
\hline & M17 & 12 & 23 & 0.52 & 10 & 35 & 0.29 & 101 & 116 & 623 \\
\hline & M18 & 8 & 11 & 0.73 & 15 & 31 & 0.48 & 28 & 121 & 526 \\
\hline Average & & 10.5 & 19.5 & 0.56 & 12.3 & 30.8 & 0.47 & & & \\
\hline
\end{tabular}


According to the uraniferous rock definition (Darnley, 1982) as any rock containing uranium at least twice the Clarke value $(4$ $\mathrm{ppm}$ ), the radiometric and chemical U-contents in El-Mueilha monzogranite and granodiorite indicate that they are mostly uraniferous one considering the probable U-leaching from some samples.

\section{Origin of Uranium}

Uranium could be directly originated from the magma fractionation, particularly in the late magmatic stage, or may be added to the rocks as a result of some post magmatic processes such as the hydrothermal solution activities.

Based on the established magmatic origin of both $\mathrm{Zr}$ and $\mathrm{Th}$, the binary relation between these elements and the uranium is used to testify the uranium origin. The binary relations of eU-eTh and eU-Zr of the monzogranite show strong positive $(r=0.9)$ and moderate correlations $(r=0.52)$ respectively, while the same relations in the granodiorite exhibit relatively moderate $(\mathrm{r}=0.48)$ and weak positive $(r=0.27)$ correlation (Fig. 47). Such relations support the magmatic origin of the present uranium in the monzogranite rather than in the granodiorite where it substitutes other elements of comparable radii into the crystal structure of the present zircon and sphene minerals. The moderate correlation between $\mathrm{Zr}$ and $\mathrm{U}$ in the monzogranite is reasonably interpreted due to the probable leaching of uranium from the partial metamectized zircon as was observed petrographically in the monzogranite.

\section{El-Mueilha Granitoids Fertility}

To examine suitability of El-Mueilha monzogranite and granodiorite as a probable environment for uranium deposition, several geologic, geochemical and radiometric parameters are considered and compared to the characteristics of fertile granites which were mentioned by Cambon (1994). Most the features are available in the studied granitoids such as; post intrusion tectonic activity with formation of various dykes and veins, the basic magmatic activities, the peraluminous magmatic nature, the relative raised $\mathrm{U}$, and $\mathrm{Th}$ values, the values of U/Th (in both radiometric and chemical measurements) is greater than 0.4 , the loss on ignition (LOI) less than $1.5 \%$ and the incompatible elements have positive correlation with the magma differentiation. All these features support the fertility of the concerned granites. On the other hand, absence of significant amount of the primary muscovite and the negative relation between $\mathrm{Th}$ and the compatible $\mathrm{Sr}$ and $\mathrm{Ba}$ elements (Fig. 48) do not support a similar conclusion.

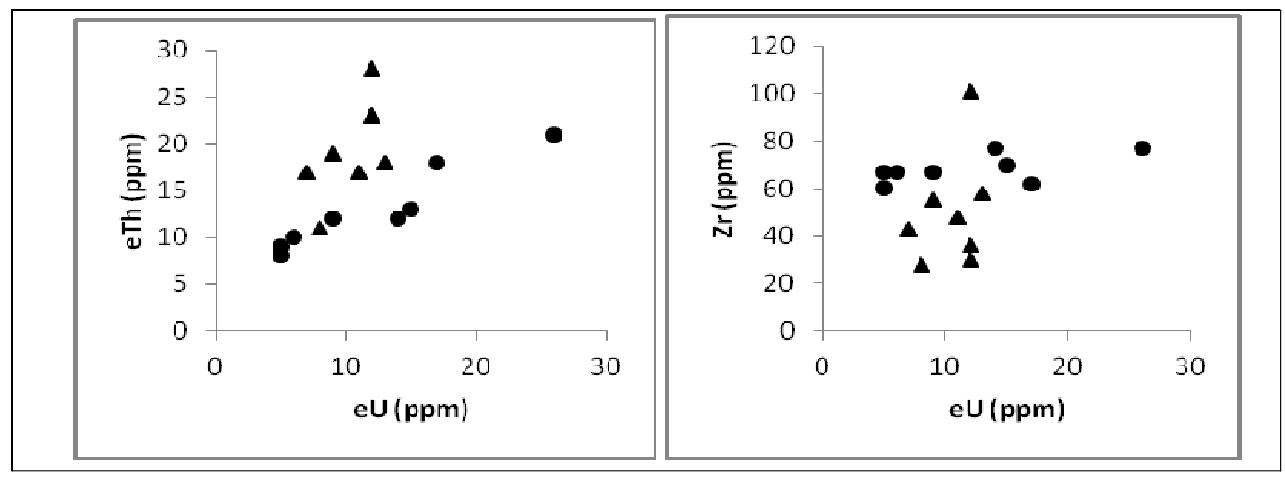

Fig.47: eU vs. eTh and eU vs. Zr of the studied monzogranite $(\bullet)$ and granodiorite $(\mathbf{\Lambda})$. 

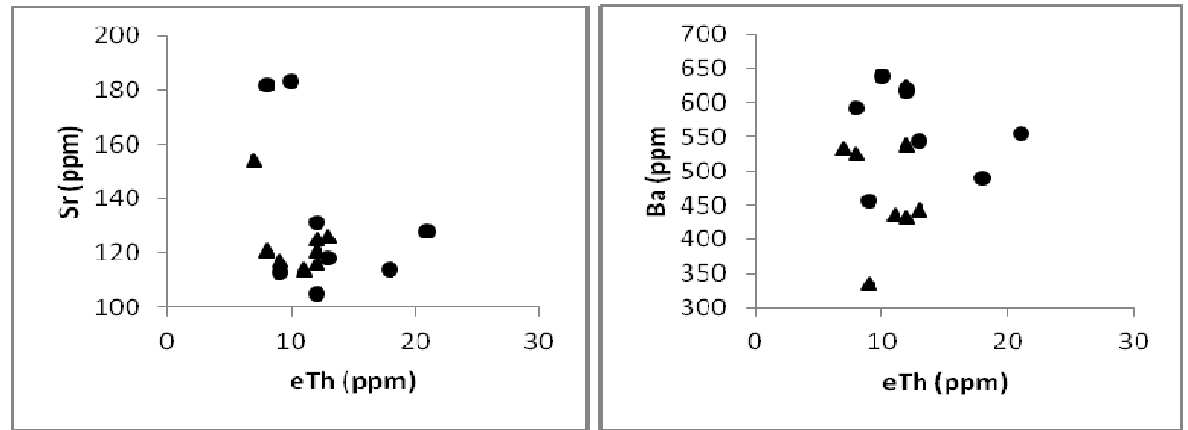

Fig.48: eTh vs. $\mathrm{Sr}$ and $\mathrm{Ba}$ show absence of positive correlation

\section{Radiometric Equilibrium}

Within a closed system, the radioactive decay process of both $U$ and $T h$ reaches the equilibrium situation when the formation rate of any intermediate daughter in the decay chain is equal to its decay rate. Under surface and near surface geological conditions the closed system may not be attained. This can be ascribed to the weathering and circulation of fluids through channels where uranium may be added or removed hence the disequilibrium arises.

The investigated monzogranite shows, to some extent, a relative wide range in its uranium contents $(5-26 \mathrm{ppm}$ and 6-22 ppm for radiometric and chemical uranium respectively). The wide range of eU contents may be attributed to redistribution of the original content during secondary (post magmatic) processes (Dardier and El-Galy, 2000). Normally, thorium is three times as abundant as uranium in rocks (Rogers \& Adams, 1969). When this ratio is disturbed, as in the studied rocks, it indicates a depletion or enrichment of uranium during post magmatic processes (Dardier et al., 2002).

The equilibrium state could be tested by measuring the $\mathrm{D}$-factor that equals the ratio of the chemically determined uranium / radiometrically determined uranium of the same sample (Hansink, 1976). If this factor was more or less than unity, it indicates addition or removal of uranium respectively (Hansink, 1976 and Stuckless et al., 1984). The calculated D-factors in the monzogranitic and granodioritic samples are listed in Table (4).

According to the calculated D-factors, the disequilibrium was verified by all the samples but there is no obvious main trend where some samples point to a case of U-addition while other samples indicate the U-removal.

In accordance, some preliminary conclusions could be reached as follows:

1-There is U-leaching from parts of the fresh granitoids and U-addition to other parts.

2-The leached uranium may have one or more of the following assumptions:

- Leached out of the pluton completely.

-Added to other parts in the same pluton

Table 4 : U chemical (U-ch.) / U radiometric (U-rad.) of the studied monzogranitic and granodioritic samples

\begin{tabular}{|c|c|c|c|c|c|c|c|c|}
\hline & & & & & & & \multicolumn{2}{|c|}{ Monzogranite } \\
\hline S.No. & M1 & M2 & M4 & M5 & M6 & M7 & M8 & M9 \\
\hline \multirow[t]{2}{*}{ U-ch/U-rad } & 2.40 & 2.67 & 1.80 & 0.93 & 0.40 & 1.56 & 0.85 & 0.35 \\
\hline & & & & & & & \multicolumn{2}{|c|}{ Granodiorite } \\
\hline S.No. & M11 & M12 & M13 & M14 & M15 & M16 & M17 & M18 \\
\hline U-ch/U-rad & 1.86 & 1.56 & 0.73 & 0.54 & 1.67 & 0.92 & 0.83 & 1.88 \\
\hline
\end{tabular}


and caused their D-factor to be more than unity.

-Enriched in certain parts, e.g. shear zones, fracture,...etc., to form surficial deposits; it might be happened.

However, the comparable number of the samples suffered U-leaching with those showed U-addition may support the second assumption, but in general absence of clear evidences to confirm and verify any of these assumptions calls for intensive and careful uranium exploration in and around El-Mueilha area that could lead to promising results.

\section{DISCUSSION AND CONCLUSION}

The meta-andesite and metadacite rock types are exposed in the studied area where they are intruded by several granitic masses and it is believed that the intrusion happened later to the over thrusting of the younger metavolcanics and is probably related to Idfo-Marsa Alam shear zone (El-Gaby et al., 1988).

According to presence of the mineral assemblage of chlorite, actinolite, epidote, sericite, zeosite, plagioclase and quartz in both the metadacite and the meta-andesite, one can conclude that these metavolcanics are subjected to low grade metamorphism of low greenschist facies (Winkler, 1979 and Bucher \& Frey, 1994).

The older granitoids are represented by medium- to coarse-grained rocks of granodioritic and Qz-dioritic composition. They are fractured and have sharp contacts with surrounding older rocks, while they are intruded by post granitic dykes. The extruded younger granitic mass in El-Mueilha is a monzogranite of fine to medium-grained and occasionally has xenoliths of the older rocks. Post-granitic intermediate and acidic dykes and pegmatitic veins transected through the granitic mass with ENE-WSW and NE-SW directions. Various post-intrusion tectonic activities are observed as faults and joints and they appear controlling the present alteration features.
Presence of post-intrusion tectonic activities and basic magmatism are among the favorable conditions which should be available in the fertile granitic rocks (Cambon, 1994).

Based on the feldspar system and its relation to the water pressure during the granitic magma crystallization (Tuttle \& Bowen, 1958 and Martin \& Bonin, 1976), both the monzogranite and the granodiorite are of subsolvus category and their magma were crystallized at high water pressure $(>5 \mathrm{~K}$. bar), on the other hand, quartz-diorite is classified as hypersolvus and its magma was crystallized at low water pressure $(<5 \mathrm{~K}$. bar $)$. Presence of both oscillatory and normal zoning in plagioclases of the monzogranite support two different generations of crystallization where both of them are developed under different crystallization conditions (Deer, et al., 1992).

According to the REE data and its normalization values, the magmas of the studied granitoids seem to be affected by more than one mechanism of the fractional crystallization, partial melting and/or assimilation with fractional crystallization, while the volcanic arc magmatism is the most probable tectonic setting for them. The Eu -ve anomaly in the monzogranite, REE-normalized pattern as well as the $\mathrm{Eu}+\mathrm{ve}$ anomalies in the normalized patterns of both the granodiorite and Qz-diorite reflect the role of the plagioclase minerals during the arising-history of their magmas. Enrichment and/or depletion of the LREE and HREE are essentially controlled by presence or absence of the pyroxenes, hornblende and zircon minerals in the parent sources of these rocks due to their variable partition coefficients regarding the REE.

The monzogranite and the granodiorite are considered uraniferous rocks (Darnley, 1982) and they posses many field, geochemical and radiometric criteria that make them as a favorable environment for uranium deposition, but the strongly probable leaching of uranium from its bearing mineral to be redistributed into other parts of the same pluton, to out of the pluton and/or to certain tectonical parts, 
e.g. shear zones, fracture, prevented formation of promising uranium concentrations. Such assumption calls for intensive uranium exploration in the surrounding territory as well as deeply along the shear zones and fault planes.

\section{REFERENCES}

Abdel Rahman, A.M., and Martin, R.F., 1990. The Mount Gharib A-type granite, Nubian Shield: petrogensis and role of metasomatism at the source. Contrib. Mineral. Petrol., 104, 173-183

Abu El-Maaty, M.A., and Ali Bik, M.W., 2000. Petrology of alkali feldspar granites of Nuweibi and Gabel El-Mueilha, Central Eastern Desert. Egy. J. Geol., 44/1, 127-148.

Azzoz, S.A.; Sabet, A.H; Dardir, A.A., and Mahmoud, Y.M., 1994. Pan-African basement of the area around Gabel-El- Mueilha, Central Eastern Desert. Egypt, Ain Shams Science Bulletin, 32 .

Bentor, Y.K., 1985. The crustal evolution of the Arabo-Nubian massif with special reference to the Sinai Peninsula, Precambrian Res., 28, 174.

Bucher, K., and Frey, M., 1994. Petrogenesis of metamorphic rocks. $6^{\text {th }}$ ed. Springer Verlag, Berlin., 318p.

Cambon, A.R., 1994. Uranium deposits in granitic rocks. Notes on the national training course on uranium geology and exploration. Organized by IAEA and NMA, 8-20 Jan. 1994, Cairo, Egypt.

Cullers, R.L., and Graf, L., 1984. Rare earth elements in igneous rocks of the continental crust: intermediate and silicic rocks ore petrogensis. In: Rare earth elements geochemistry (Henderson, P., Ed.). El-Sevier Publ. Co., Amsterdam, 2, 275-316.

Dardier, A.M., and El-Galy, M.M., 2000. Contribution to the U-Th distribution in the older and younger granitoids along Qena-Safaga road, Central Eastern Desert, Egypt. Egypt. J. Geol., 44 (1), 55-64.

Dardier, A.M.; Farag, S.S.; Abdel Ghani, I.M.; Arb- ab, A.A.; Abd El-Shafi, A.; Omran, A.A.; Ibrahim, S.E., and Zaher, F.Y., 2002. Geological and radiometric prospection for Wadi Hawashiya-Gabal Um El-Tanasub area, North Eastern Desert, Egypt. Inter. report in the Nuclear Materials Authority of Egypt (NMA).

Darnley, A.G., 1982. Hot granites, Some general remarks. In: Uranium in granites (Maurice, Y.J.,Ed.). Geol. Surv. Canada, paper No. 81-23, $1-10$.

Deer, W.A.; Howie, R.A., and Zussmann, J., 1992. An introduction to the rock forming minerals. Longmans, London, England. Second edition, $696 \mathrm{p}$.

El-Gaby, S.; List, F.K., and Tehrani, R., 1988. Geology, evolution and metallo-genesis of the PanAfrican belt in Egypt. In : The Pan-African belt of NE Africa and adjacent area (El-Gaby, S. \& Greiling, R.O. ,Eds.). Vieweg, Braunschweig, 17-68.

El-Sayed, M.M.,1998. Tectonic setting and petrogenesis of the Kadabora pluton: a late Proterozoic anorogenic A-type younger granitoid in the Egyptian Shield. Chem Erde, 58, 38-63.

Fowler, A.D., and Doig, R., 1983. The significance of europium anomalies in the REE spectra of granites and pegmatites, Mont Laurier, Quebec. Geochemica Cosmochemica Acta, 47, 11311137.

Granne, T., and Roberts, D., 1998. The Holonda prophyrite, Norwegian Caledonides: geochemistry and tectonic setting of Early-Mid-Ordovician shoshonitic volcanism. J. Geol. Soc., London, 155, 131-142.

Greenberg, J.K., 1981. Characteristics and origin of Egyptian younger granites: summary. Bull. Geol. Soc. Am., 92, 224-232.

Hansink, J.D., 1976. Equilibrium analyses of sandstone roll-front uranium deposits, International Atomic Energy Agency, Vienna, 683-693.

Hassan, M.A., and Hashad, A.H., 1990. Precambrian of Egypt. In: The Geology of Egypt (Said, R.,Ed.). Rotterdam, 201-245. 
Hussien, A.H., and Ghazaly, M.A., 1991. Geochemistry of arc volcanic at El Mueilha area, Eastern Desert, Egypt. Geol. Bull. Fac. Sci., Assuit Univ., 20 (1-f), 125-145.

Jahn, S.; Matheis, G.; Mohamed, F. H.; Tamish, M. O., and Shalaby, I.M., 1993. Rare-metal province central Eastern Desert, Egypt-III. Geochemical indicators of rare-metal potentials. (A contribution to IGCP 282 'Rare-metal mineralization'). In: Geoscientific research in Northeast Africa ( Thorweihe, U. \& Schandelmeier, H.,Eds.). Belkema, Rotterdam, 489-494.

Kamel, A.F., 1983. Relationship between photolineaments and radioactivity in Gabal El-Mueilha, Central Eastern Desert, Egypt. J. Afri. Earth Sci., 1, 343- 347.

Martin, R., and Bonin, B., 1976. Water and magma genesis, the association hypersolvus granite - subsolvus granite. Cand. Mineral., 14, 281285.

Mohamed, F.H., 1996. Geochemistry of Bir Um Hibal complex: alkaline syenites and granites from the Eastern Desert of Egypt. Chem. Erde., $56,45-64$.

Mohamed, F.H., and Kanisawa, S., 1999. The PanAfrican intrusive complex of Ghorabat area, Southern Egypt: geochemical and mineralogical constraints on arc-related and anorogenic magmatism. Chem. Erde., 59, 259-286.

Mohamed, F.H.; Moghazi, A.M., and Hassanen, M.A., 1999. Petrogenesis of late Proterozoic granitoids in the Ras Gharib magmatic province, northern Eastern Desert, Egypt: Petrological and geochemical constraints. N Jahrb Mineral Abh., 174, 319-353.

Noweir, A.M.; Sewift, B.M., and Abuel Ela, A.M., 1990. Geology, petrography, geochemistry and petrogenesis of the Egyptian younger granites. Qatar Univ. Sci. Bull., 10, 363-393.

Rogers, J.J., and Adams, J.A., 1969. Uranium and thorium. In: Handbook of geochemistry (Wedepohl, K. H., Ed.) .Springer Verlag, Berlin.
Rollinson, H.R., 1993. Using geochemical data: evaluation, presentation and interpretation. John Wiley and Sons. Inc. New York.

Shelly, D., 1993. Igneous and metamorphic rocks under the microscope. Chapman and Hall, London.

Soliman, M.M., 1984. Ore element distribution in the Mueilha tin mine area, South Eastern Desert, Egypt. J. Univ. Kuwait (Sci.), 11, 97-112.

Stern, R.J., 1979. Late Precambrian ensimatic volcanism in the Central Eastern Desert of Egypt. Ph. D. Thesis. California Univ., U. S. A., 210p.

Stern, R.J., 1985. The Najd fault system, Saudi-arabia and Egypt: a late Precambrian rift-related transform system. Tectonics., 4, 497-511

Streckeisen, A.L., 1976b. To each plutonic rock its proper name. Earth Sci. Rev., 12, 1-15.

Stuckless, J.S.; Nkomo, I.T.; Wenner, D.B., and Van Trump, G., 1984. Geochemistry and uranium favourability of the post-orogenic granites of the northwestern Arabian Shield, Kingdom of Saudi Arabia. In: Pan African crustal evolution in the Arabian -Nubian Shield (Convenor, A.M. Alshanti), Bull. Fac. Earth Sci. KAU (Jeddah), 6, 195-210, B. Bergamon Press. Oxford.

Taylor, S.R.; Arculus, R.; Perfit, M.R., and Johnson, R.W., 1981. Island arc basalts, in basaltic volcanism on the terrestrial planets (basaltic volcanism study project). New York, Pergamon Press., 193-213.

Taylor, S.R., and Mclennan, S.M., 1985. The continental crust: its composition and evolution. Blackwell, Oxford, 312p.

Tuttle, O.F., and Bowen, N.L., 1958. Origin of granite in the light of experimental studies in the system $\mathrm{Na} \mathrm{Al} \mathrm{Si}_{3} \mathrm{O}_{8}-\mathrm{SiO}_{2}-\mathrm{H}_{2} \mathrm{O}$. Geol. Soc. Am. Mem, 74, 153p.

Winkler, H.G.F., 1979. Petrogenesis of metamorphic rocks, $4^{\text {th }}$ ed., 334 pp. Springer Verlag, New York, Heidelberg, Berlin. 


\title{
مشاركه فى جيولوجية و توزيع اليورانيوم فى بعض صخور القاعده بمنطقة

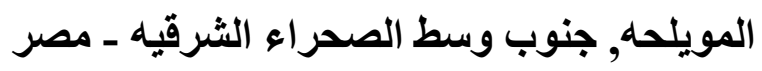

\author{
طارق فهمى محمدين, نجدى محمد فرج عبده, محمود محمد بدران
}

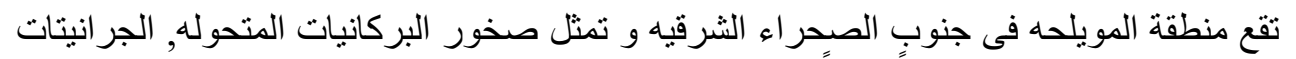

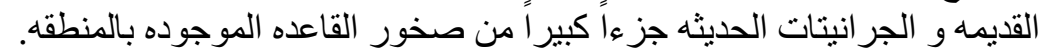

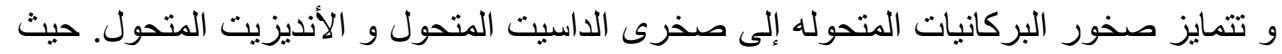

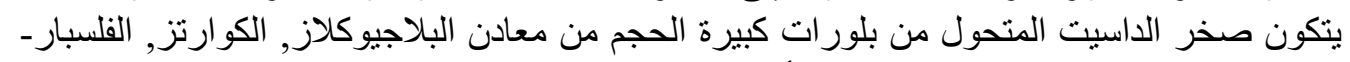

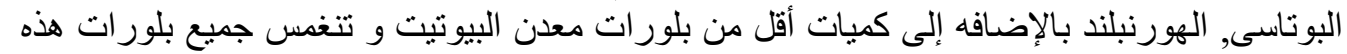

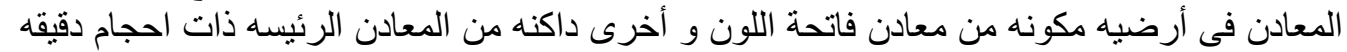

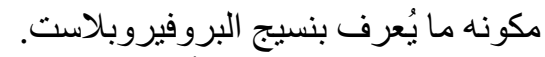

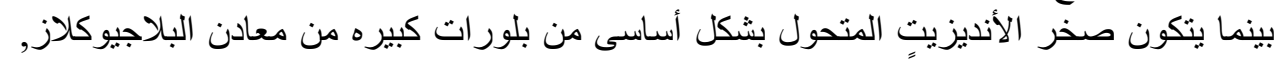

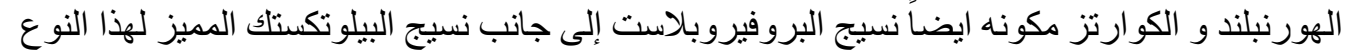

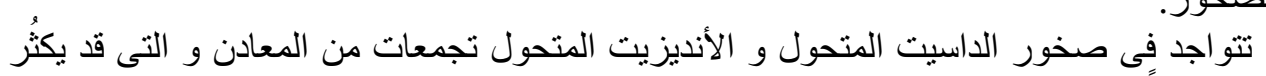

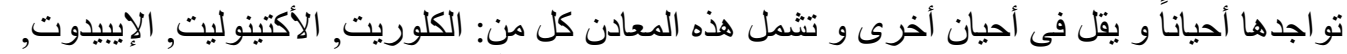

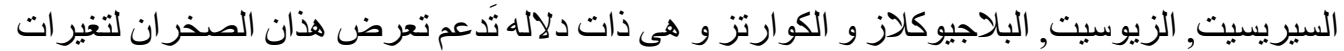

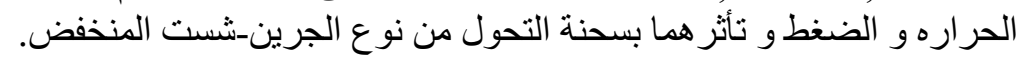

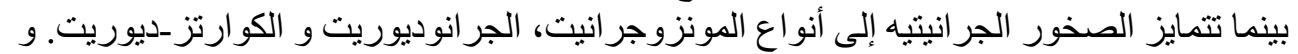

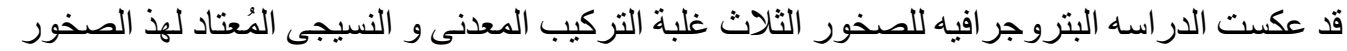

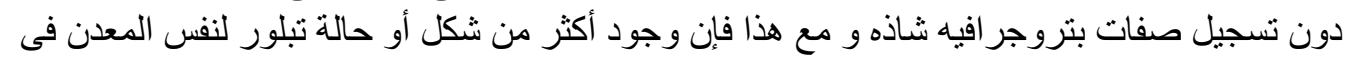

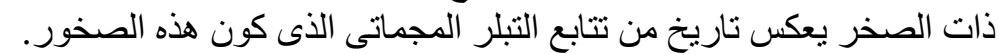

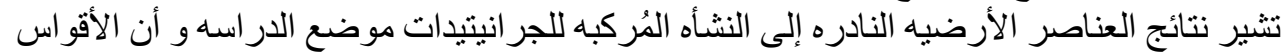

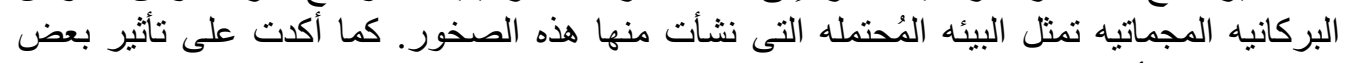

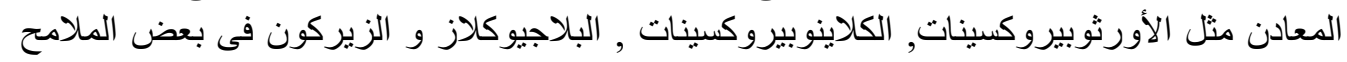

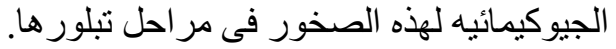

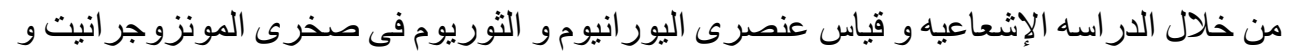

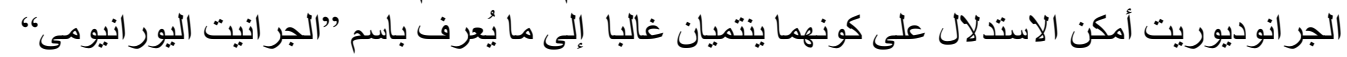

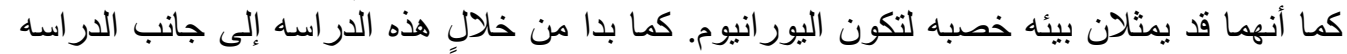

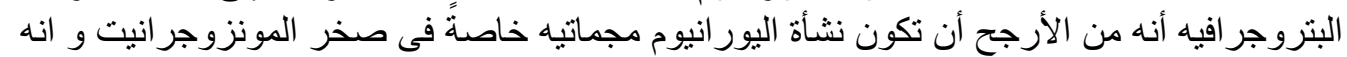

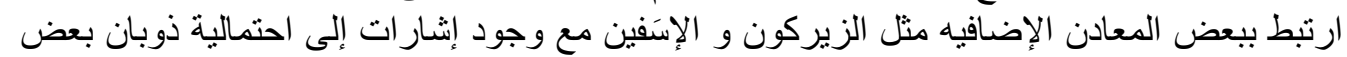

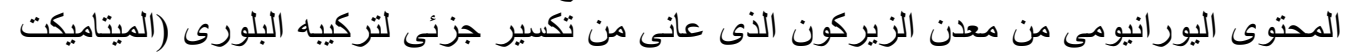

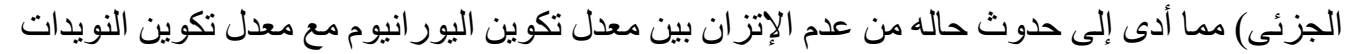

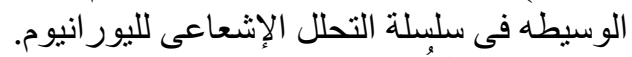

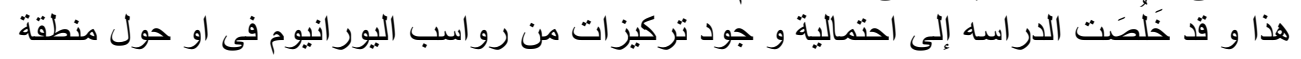




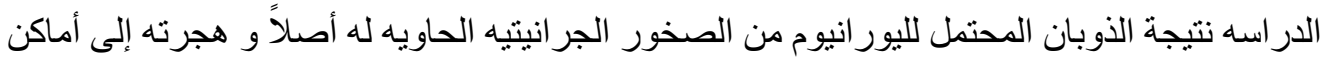

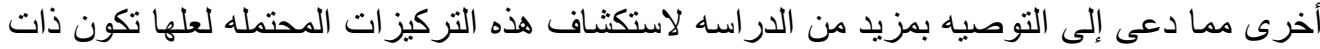
قيمه اقتصاديه. 